Article

\title{
Enhanced Photocatalytic Activity of Titania by Co-Doping with Mo and W
}

\author{
Osmín Avilés-García ${ }^{1}$, Jaime Espino-Valencia ${ }^{1, *}$, Rubí Romero-Romero ${ }^{2}$, José Luis Rico-Cerda ${ }^{1}$, \\ Manuel Arroyo-Albiter ${ }^{1}$, Dora Alicia Solís-Casados ${ }^{2}$ and Reyna Natividad-Rangel ${ }^{2, *}$ \\ 1 Facultad de Ingeniería Química, Universidad Michoacana de San Nicolás de Hidalgo, Edif. V1, Ciudad \\ Universitaria, Morelia 58060, Michoacán, Mexico; agosmin@gmail.com (O.A.-G.); \\ jlceri@yahoo.com.mx (J.L.R.-C.); albitmanuel@gmail.com (M.A.-A) \\ 2 Centro Conjunto de Investigación en Química Sustentable, UAEMéx-UNAM, Universidad Autónoma del \\ Estado de México, Km 14.5 Carretera Toluca-Atlacomulco, San Cayetano, Piedras Blancas, 50200 Toluca, \\ MEX, Mexico; rubiromero99@gmail.com (R.R.R.); solis_casados@yahoo.com.mx (D.A.S.-C.) \\ * Correspondence: rnatividadr@uaemex.mx (R.N.-R.); jespinova@yahoo.com.mx (J.E.-V.); \\ Tel.: +52-722-2766610 (ext. 7723) (R.N.-R.); +52-443-3223500 (ext. 2002) (J.E.-V.)
}

Received: 22 October 2018; Accepted: 19 November 2018; Published: 6 December 2018

\begin{abstract}
Various $\mathrm{W}$ and Mo co-doped titanium dioxide $\left(\mathrm{TiO}_{2}\right)$ materials were obtained through the EISA (Evaporation-Induced Self-Assembly) method and then tested as photocatalysts in the degradation of 4-chlorophenol. The synthesized materials were characterized by thermogravimetric analysis (TGA), Fourier transform infrared (FTIR) spectroscopy, X-ray diffraction (XRD), Raman spectroscopy (RS), $\mathrm{N}_{2}$ physisorption, UV-vis diffuse reflectance spectroscopy (DRS), X-ray photoelectron spectroscopy (XPS), and transmission electron microscopy (TEM). The results showed that the W-Mo- $-\mathrm{TiO}_{2}$ catalysts have a high surface area of about $191 \mathrm{~m}^{2} / \mathrm{g}$, and the presence of an anatase crystalline phase. The co-doped materials exhibited smaller crystallite sizes than those with one dopant, since the crystallinity is inhibited by the presence of both species. In addition, tungsten and molybdenum dopants are distributed and are incorporated into the anatase structure of $\mathrm{TiO}_{2}$, due to changes in red parameters and lattice expansion. Under our experimental conditions, the co-doped $\mathrm{TiO}_{2}$ catalyst presented 46\% more 4-chlorophenol degradation than Degussa P25. The incorporation of two dopant cations in titania improved its photocatalytic performance, which was attributed to a cooperative effect by decreasing the recombination of photogenerated charges, high radiation absorption capacity, high surface areas, and low crystallinity. When $\mathrm{TiO}_{2}$ is co-doped with the same amount of both cations ( $1 \mathrm{wt} . \%)$, the highest degradation and mineralization $(97 \%$ and $74 \%$, respectively) is achieved. Quinones were the main intermediates in the 4-chlorophenol oxidation by $\mathrm{W}-\mathrm{Mo}-\mathrm{TiO}_{2}$ and 1,2,4-benzenetriol was incompletely degraded.
\end{abstract}

Keywords: W-Mo dopants; titanium dioxide; nanoparticles; photocatalytic activity

\section{Introduction}

Among the advanced oxidation processes (AOPs), heterogeneous photocatalysis is considered as an efficient method for the degradation of organic pollutants in water and air [1,2]. Numerous semiconductors have been investigated as photocatalysts. Among the semiconductors used, titanium dioxide $\left(\mathrm{TiO}_{2}\right)$ is the most promising and widely studied material for photocatalytic applications due to its chemical stability, high efficiency, photostability, high oxidizing power, abundance, nontoxicity, and low cost $[3,4]$. The main quality of $\mathrm{TiO}_{2}$ is attributed to oxidative power of hydroxyl radicals generated when the electrons are photoexcited by UV light absorption [5]. However, the recombination of the charge pair (holes and electrons) should not be ignored because it decreases the photoactivity. 
In order to avoid this and improve the photocatalytic activity, the photogenerated charges must be trapped on $\mathrm{TiO}_{2}$ surface, thus reducing recombination [6]. In this context, several techniques such as doping with metals and non-metals [7], dye sensitization [8], deposition with noble metals [9], and coupled semiconductor [10] have been assessed. Among these studies, doping has shown positive effects on titania because it gives unique electronic and structural properties that translate into better activity. Doping with non-metallic ions usually introduces energy levels above the valence band of the semiconductor for photon absorption in the visible-light region [11]. Alternatively, the use of dopant metals promotes charge transfer and separation of photogenerated charges [12]. In addition, concentration and distribution of dopant ions in $\mathrm{TiO}_{2}$ are factors that must be considered for a good photocatalytic performance [13]. The incorporation of two types of cations into $\mathrm{TiO} 2$ lattice and its photocatalytic performance has been reported in several studies [14,15]. Estrellan et al. [14] reported that when the $\mathrm{TiO} 2$ is co-doped with iron and niobium, the photocatalytic efficiency is improved due to synergistic actions between the doping species, which favor the $\mathrm{e}-/ \mathrm{h}+$ generation and reduce the recombination rate. Shi et al. [15] reported enhanced photoactivity of titania with iron and cerium by co-doping, which is due to cooperative effects of both dopants, by broadening the absorption spectrum and retarding the recombination of the photogenerated charges.

The synthesis of the catalysts was carried out by Evaporation-Induced Self-Assembly (EISA) method, which allows obtaining mesoporous structures with high surface areas [16]. On the other hand, 4-chlorophenol oxidation was chosen as the reaction to evaluate the synthesized materials, because it is considered as a model molecule for photocatalytic evaluations [17]. However, it is important to mention that the removal of chlorophenols can be carried out by other techniques, such as hydrodechlorination, which has been the subject of many investigations [18,19]. 4-chlorophenol is a pollutant commonly found in the effluents from industries related to insecticides, dyes, plastics, herbicides, detergents, wood preservatives, and petroleum reforming [20]. In addition, it is classified by the U.S. Environmental Protection Agency (USEPA) as a very toxic pollutant in these effluents, since it causes damage to human health and aquatic environments, so its effective removal is of great interest [21].

In this work, samples of $\mathrm{TiO}_{2}$ co-doped with transition metals tungsten $(\mathrm{W})$ and molybdenum (Mo) were synthesized by the EISA method. In addition, these materials have not been reported previously. The resulted solids were characterized and their photocatalytic activity evaluated in the degradation and mineralization of 4-chlorophenol. This was conducted with the main objective of demonstrating a synergistic effect in terms of improved photoactivity by co-doping compared to $\mathrm{W}$-doped and Mo-doped $\mathrm{TiO}_{2}$ catalysts. Results were compared to those obtained with commercial Degussa $\mathrm{P} 25 \mathrm{TiO}_{2}$.

\section{Results and Discussion}

\subsection{Photocatalysts Characterization}

Thermal analysis (TGA) of the synthesized titania without dopants is shown in Figure 1. A weight loss $(9 \%)$ from room temperature to $200^{\circ} \mathrm{C}$ can be observed, which is assigned to desorption of water and residual organic solvents [22]. Subsequently, a significant weight loss (34\%) between $200{ }^{\circ} \mathrm{C}$ and $300{ }^{\circ} \mathrm{C}$ is attributed to the elimination of P123 organic surfactant. Finally, the dehydroxylation process is observed above $300{ }^{\circ} \mathrm{C}$. The thermogravimetric graph of the $\mathrm{TiO}_{2}$ sample co-doped with $1 \mathrm{wt} . \%$ tungsten and $1 \mathrm{wt} . \%$ molybdenum is shown in Figure 1. For comparison purposes, it can be observed that the incorporation of dopant cations into titania reduces the percentage of total weight loss, which resulted in a better thermal stability, as previously observed by Hussain et al. [23]. The applied heat treatment $\left(400{ }^{\circ} \mathrm{C}\right.$ as maximum temperature) ensured the complete elimination of the organic surfactant in all synthesized samples. On the other hand, infrared analysis (FTIR) before and after heat treatment were carried out to corroborate the P123 elimination (see Figure 2). Before thermal treatment, the characteristic signals of the surfactant by IR at 1090, 1640, 2850, and $3250 \mathrm{~cm}^{-1}$ are attributed 
to the $\mathrm{C}-\mathrm{H}, \mathrm{H}-\mathrm{O}-\mathrm{H}, \mathrm{O}-\mathrm{H}$, and C-C bonds vibrations, respectively [24]. After heat treatment, these characteristic bands disappear, which confirms the complete elimination of the organic compound incorporated during the synthesis.

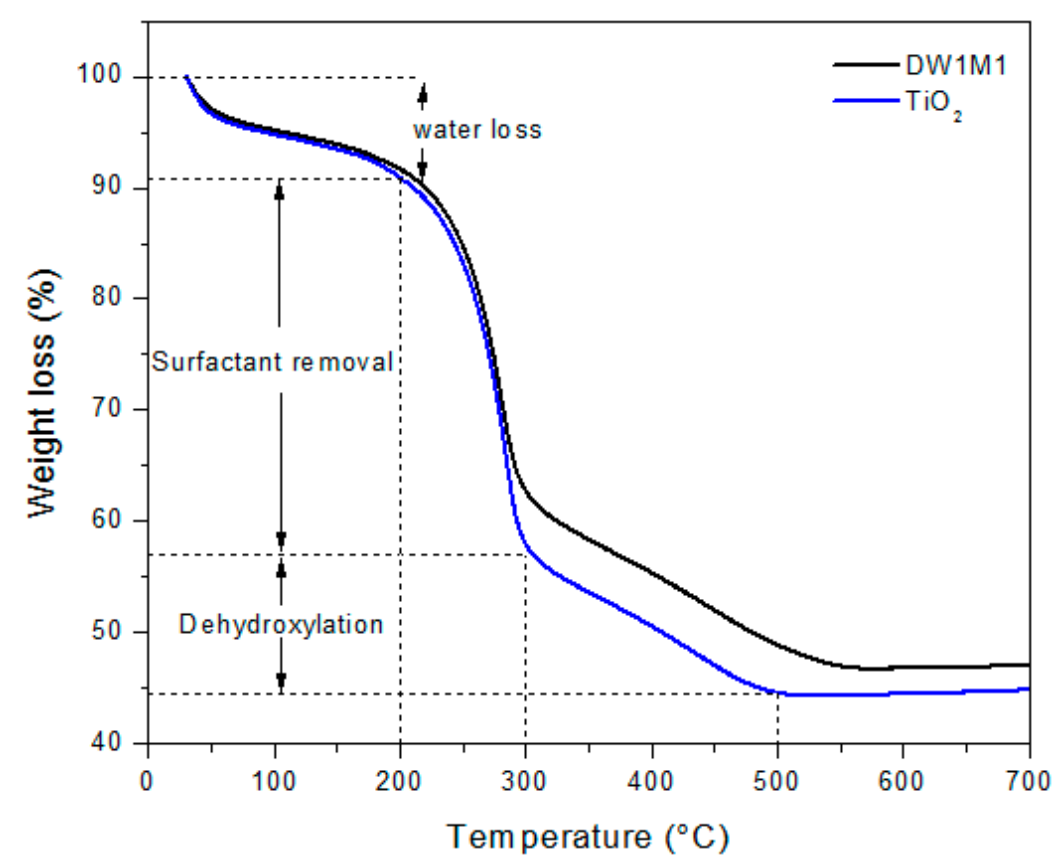

Figure 1. Thermogravimetric analysis of pure $\mathrm{TiO}_{2}$ and $\mathrm{TiO}_{2}$ co-doped with 1 wt.\% tungsten and molybdenum (DW1M1).

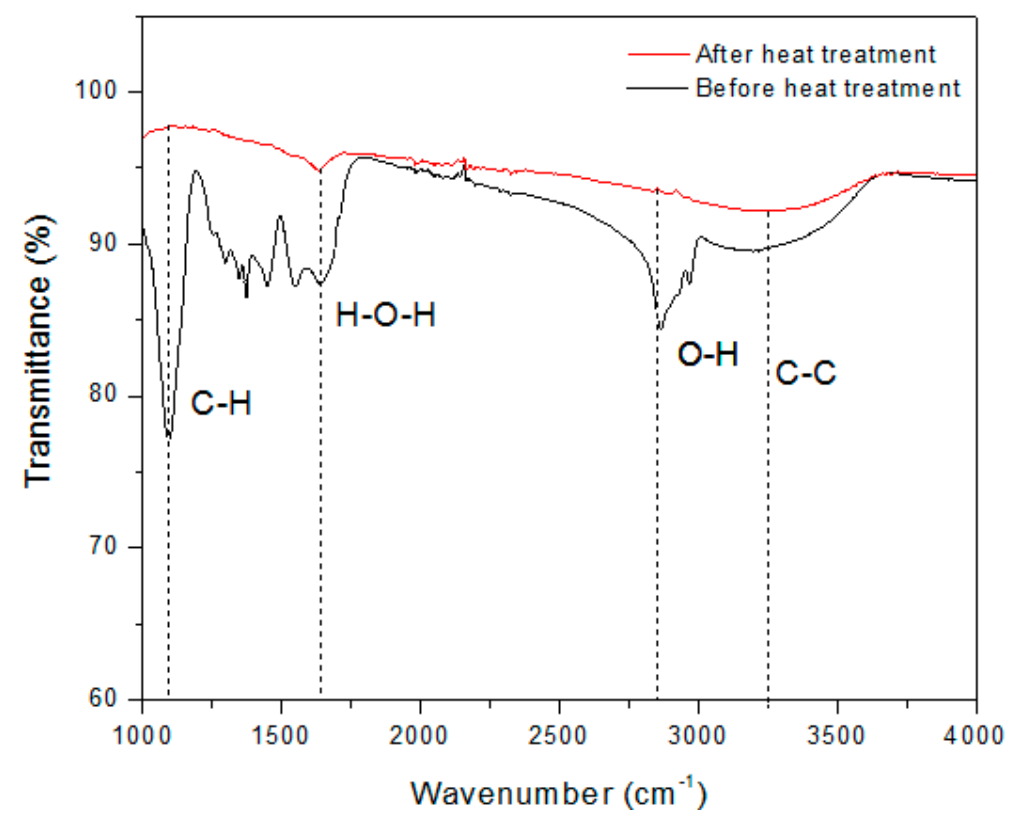

Figure 2. Infrared spectra of pure $\mathrm{TiO}_{2}$ sample before and after thermal treatment.

Figure 3 shows the $\mathrm{X}$-ray diffraction (XRD) patterns of all synthesized samples. The materials exhibited reflections at $2 \theta \approx 25.4^{\circ}, 37.8^{\circ}, 48.1^{\circ}, 54.2^{\circ}, 55.2^{\circ}$, and $62.6^{\circ}$, which are representative of the crystalline planes (101), (004), (200), (105), (211), and (204) of the anatase $\mathrm{TiO}_{2}$ phase, respectively [25]. The average crystallite sizes according to the Scherrer equation, as well as the lattice distortion of the samples are shown in Table 1. The crystal size of $\mathrm{TiO}_{2}(8.6 \mathrm{~nm})$ and DM2 $(8.6 \mathrm{~nm})$ is higher compared to the co-doped titania samples, whose values are in the range between $6.6 \mathrm{~nm}$ and $8.3 \mathrm{~nm}$. This suggests that the inclusion of tungsten and molybdenum into the $\mathrm{TiO}_{2}$ matrix suppresses crystalline 
growth. No relationship was observed due to the increase in weight percentage of a second cation by co-doping with respect to the average crystallite size. The lattice parameters and the unit cell volume of the materials are shown in Table 1. As can be seen, the incorporation of $W$ and Mo in the titania by co-doping further increases the c-axis in comparison with the mono-doping, which indicates a greater expansion of the crystal lattice. Since the ion radii of $\mathrm{Mo}^{6+}(0.062 \mathrm{~nm})$ and $\mathrm{W}^{6+}(0.060 \mathrm{~nm})$ are very similar to that of $\mathrm{Ti}^{4+}(0.0605 \mathrm{~nm})$, they can replace titanium within the anatase structure [26]. These changes in the lattice parameters are associated with lattice distortion due to the inclusion of dopants in the $\mathrm{TiO}_{2}$ matrix.

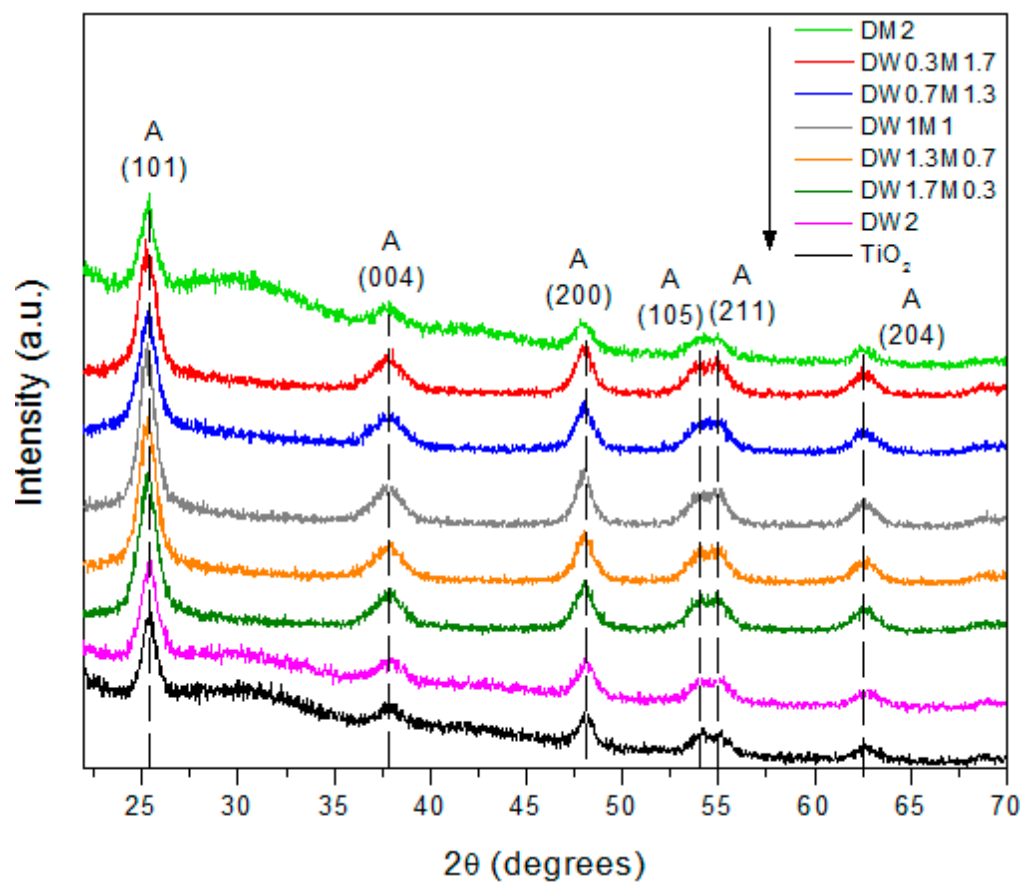

Figure 3. X-ray diffraction patterns of all prepared catalysts.

Table 1. Crystal size, lattice distortion and lattice parameters of the synthesized materials.

\begin{tabular}{cccccc}
\hline \multirow{2}{*}{ Sample } & \multirow{2}{*}{$\begin{array}{c}\text { Average Crystallite } \\
\text { Size }(\mathbf{n m})\end{array}$} & \multirow{2}{*}{$\begin{array}{c}\text { Lattice } \\
\text { Distortion }(\varepsilon)\end{array}$} & $\mathbf{a}(\mathbf{n m})$ & $\mathbf{c}(\mathbf{n m})$ & $\mathbf{V}\left(\mathbf{n m}^{\mathbf{3}}\right)$ \\
\cline { 4 - 6 } & 8.6 & 0.0183 & 0.377 & 0.931 & 0.132 \\
$\mathrm{TiO} 2$ & 8.6 & 0.0183 & 0.378 & 0.933 & 0.133 \\
DM2 & 7.7 & 0.0207 & 0.378 & 0.982 & 0.140 \\
DW0.3M1.7 & 6.6 & 0.0238 & 0.378 & 0.943 & 0.135 \\
DW0.7M1.3 & 8.3 & 0.0191 & 0.379 & 0.937 & 0.134 \\
DW1M1 & 7.3 & 0.0216 & 0.378 & 0.947 & 0.136 \\
DW1.3M0.7 & 7.1 & 0.0224 & 0.379 & 0.959 & 0.138 \\
DW1.7M0.3 & 8.1 & 0.0195 & 0.379 & 0.933 & 0.134 \\
DW2 & & & & &
\end{tabular}

Figure 4 shows Raman spectra (RS) of $\mathrm{TiO}_{2}, \mathrm{~W}-\mathrm{TiO}_{2}, \mathrm{Mo}-\mathrm{TiO}_{2}$, and $\mathrm{W}-\mathrm{Mo}-\mathrm{TiO}_{2}$ samples. As observed in Figure 4a, some peaks centered at 144, 197, 397, 517, and $640 \mathrm{~cm}^{-1}$ are assigned to the $\mathrm{E}_{\mathrm{g}(1)}$, $\mathrm{E}_{\mathrm{g}(2)}, \mathrm{B}_{1 \mathrm{~g}(1)},\left(\mathrm{A}_{1 \mathrm{~g}}+\mathrm{B}_{1 \mathrm{~g}(2)}\right)$, and $\mathrm{E}_{\mathrm{g}(3)}$ vibration modes, respectively, corresponding to anatase crystalline phase [27]. This suggests that, after doping with $W$ and/or Mo cations, the anatase phase is maintained on the $\mathrm{TiO}_{2}$ surface, which is in accordance with the XRD results. The position and intensity of the most intense Raman peak at $144 \mathrm{~cm}^{-1}$ change when titania is mono-doped and co-doped with these kinds of cations (see Figure $4 \mathrm{~b}$ ), which is attributed to changes in lattice parameters and unit cell volume by XRD analysis (see Table 1) [28]. This shift Raman is related to the increase in the c lattice parameter and the lattice expansion, which is due to the incorporation of $\mathrm{W}$ and/or Mo dopant ions 
into anatase, generating structural distortion [29]. In addition, the absence of new Raman bands in the spectra implies that there are no additional phases, which means that the dopants have been incorporated and they are well distributed in the crystal structure of $\mathrm{TiO}_{2}$ [30].
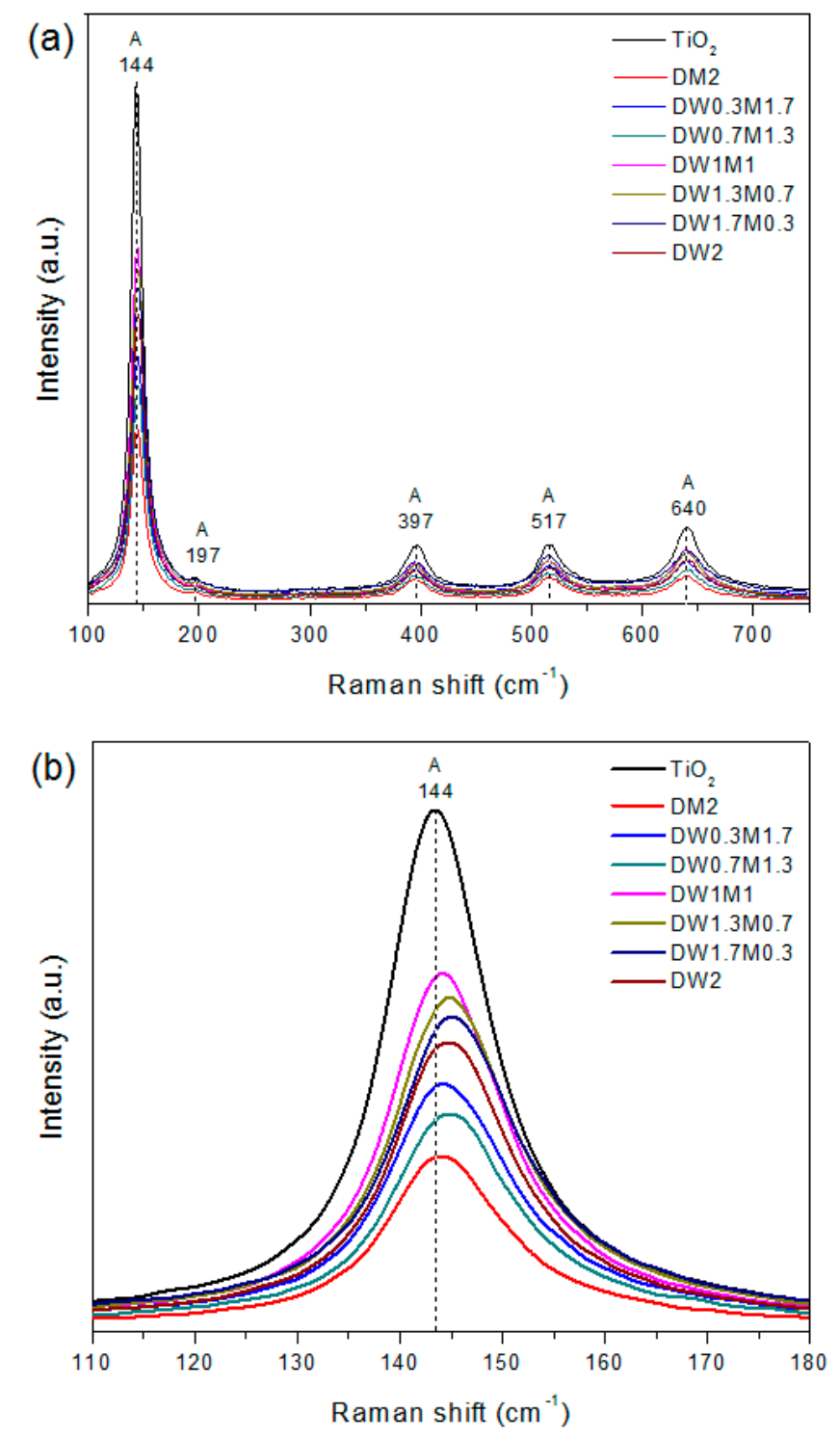

Figure 4. (a) Raman spectra and (b) Raman peak at $144 \mathrm{~cm}^{-1}$ of all synthesized materials.

The nitrogen adsorption-desorption isotherms and pore size distributions of all prepared materials are shown in Figures 5 and 6, respectively. The samples exhibited type IV isotherm, which is characteristic of mesoporous materials [31] according to the IUPAC (International Union of Pure and Applied Chemistry) classification. Type H2 hysteresis loop with monomodal pore size distribution is attributed to porous structures formed by interconnected networks. Table 2 presents the specific surface area, average pore diameter, and pore volume of all samples. The specific surface area of the co-doped samples is higher than the doped ones (DW2 and DM2), which is probably due to the incorporation of $\mathrm{W}$ and Mo in the crystal structure as well as the decrease in crystallinity. The maximum specific surface area of $191 \mathrm{~m}^{2} / \mathrm{g}$ is obtained with sample DW0.7M1.3. No relationship was observed between the surface area and the concentration of a second dopant cation, however, when $\mathrm{W}$ or Mo is incorporated in a small amount ( $0.33 \mathrm{wt} . \%)$ by co-doping (DW1.7M0.3 and DW0.3M1.7 samples), the specific surface area increases by approximately $15 \%$ with respect to mono-doped $\mathrm{TiO}_{2}$. High surface areas may offer more adsorption sites for photocatalytic reactions, which could result in 
better photoactivity [32]. Additionally, the average pore diameter of the co-doped catalysts remained constant $(5.6 \mathrm{~nm})$ and with a value between that of the mono-doped catalysts $(4.6 \mathrm{~nm}$ and $6.1 \mathrm{~nm})$, with the exception of sample DW1M1 that exhibited the highest average pore diameter of $6.6 \mathrm{~nm}$ and the maximum pore volume of $0.391 \mathrm{~cm}^{3} / \mathrm{g}$.
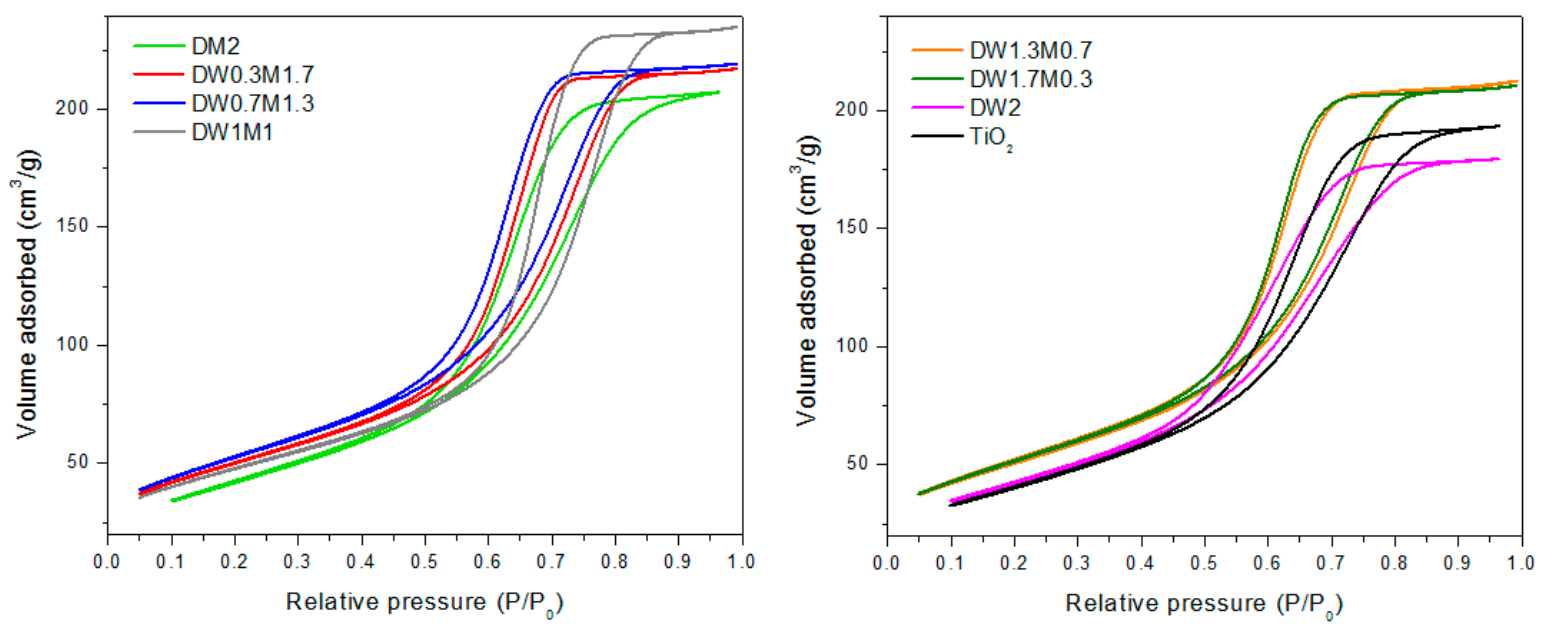

Figure 5. $\mathrm{N}_{2}$ adsorption-desorption isotherms of undoped, doped, and co-doped $\mathrm{TiO}_{2}$ with different weight percentages of $\mathrm{W}$ and Mo ions.
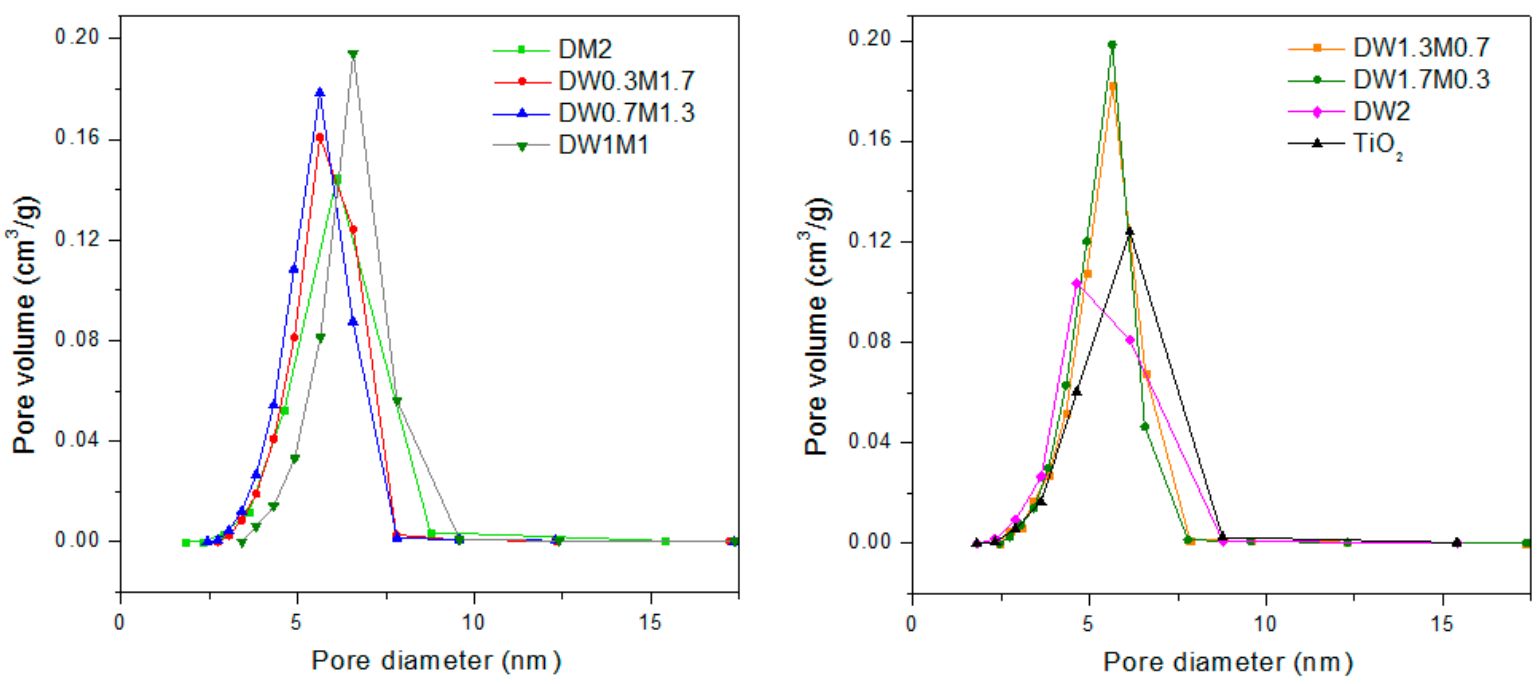

Figure 6. Pore size distributions of undoped, doped, and co-doped $\mathrm{TiO}_{2}$ with different weight percentages of $\mathrm{W}$ and Mo ions.

Table 2. Textural properties of $\mathrm{TiO}_{2}, \mathrm{~W}-\mathrm{TiO}_{2}, \mathrm{Mo}-\mathrm{TiO}_{2}$, and $\mathrm{W}-\mathrm{Mo}-\mathrm{TiO}_{2}$ catalysts.

\begin{tabular}{|c|c|c|c|}
\hline Catalyst & Specific Surface Area $\left(\mathrm{m}^{2} / \mathrm{g}\right)$ & Average Pore Diameter (nm) & Pore Volume $\left(\mathrm{cm}^{3} / \mathrm{g}\right)$ \\
\hline $\mathrm{TiO}_{2}$ & 144 & 6.1 & 0.328 \\
\hline DM2 & 161 & 6.1 & 0.354 \\
\hline DW0.3M1.7 & 181 & 5.6 & 0.362 \\
\hline DW0.7M1.3 & 191 & 5.6 & 0.365 \\
\hline DW1M1 & 172 & 6.6 & 0.391 \\
\hline DW1.3M0.7 & 185 & 5.6 & 0.352 \\
\hline DW1.7M0.3 & 188 & 5.6 & 0.352 \\
\hline DW2 & 160 & 4.6 & 0.307 \\
\hline
\end{tabular}

The catalysts were analyzed by UV-vis diffuse reflectance spectroscopy (DRS) to estimate their band gap energy. Figure 7a shows the UV-vis absorption spectra for all materials. As can be seen, 
the concentration of molybdenum cations in the titania gradually shifts the absorption edge towards the long wavelength region. Figure $7 \mathrm{~b}$ shows the Tauc plots from the Kubelka-Munk function [33]. The band gap and its corresponding wavelength are presented in Table 3 for all synthesized samples. $\mathrm{TiO}_{2}$ doped with $2 \mathrm{wt} . \%$ tungsten did not show a significant reduction in band gap energy $(3.08 \mathrm{eV})$. However, titania doped with $2 \mathrm{wt} . \%$ molybdenum showed a slight shift towards visible radiation absorption at $452 \mathrm{~nm}$ and a band gap energy of $2.74 \mathrm{eV}$. The incorporation and increase of tungsten by co-doping does not favor the band gap reduction, since the " $\mathrm{d}$ " orbitals of $\mathrm{W}$ are located into the conduction band of $\mathrm{TiO}_{2}$, making it difficult to generate energy levels under this band [34]. On the other hand, the increase of molybdenum by co-doping favors the band gap reduction due to charge transfer transitions between the " $\mathrm{d}$ " orbitals of molybdenum and $\mathrm{TiO}_{2}$ located under the conduction band. The incorporation of this type of dopant cations ( $\mathrm{W}$ and $\mathrm{Mo}$ ) does not exhibit cooperative effects by co-doping towards an effective reduction of the band gap in anatase, so that its absorption of energy for electronic excitation is between the limits of mono-doped materials (DW2 and DM2 samples) at $403-452 \mathrm{~nm}$.
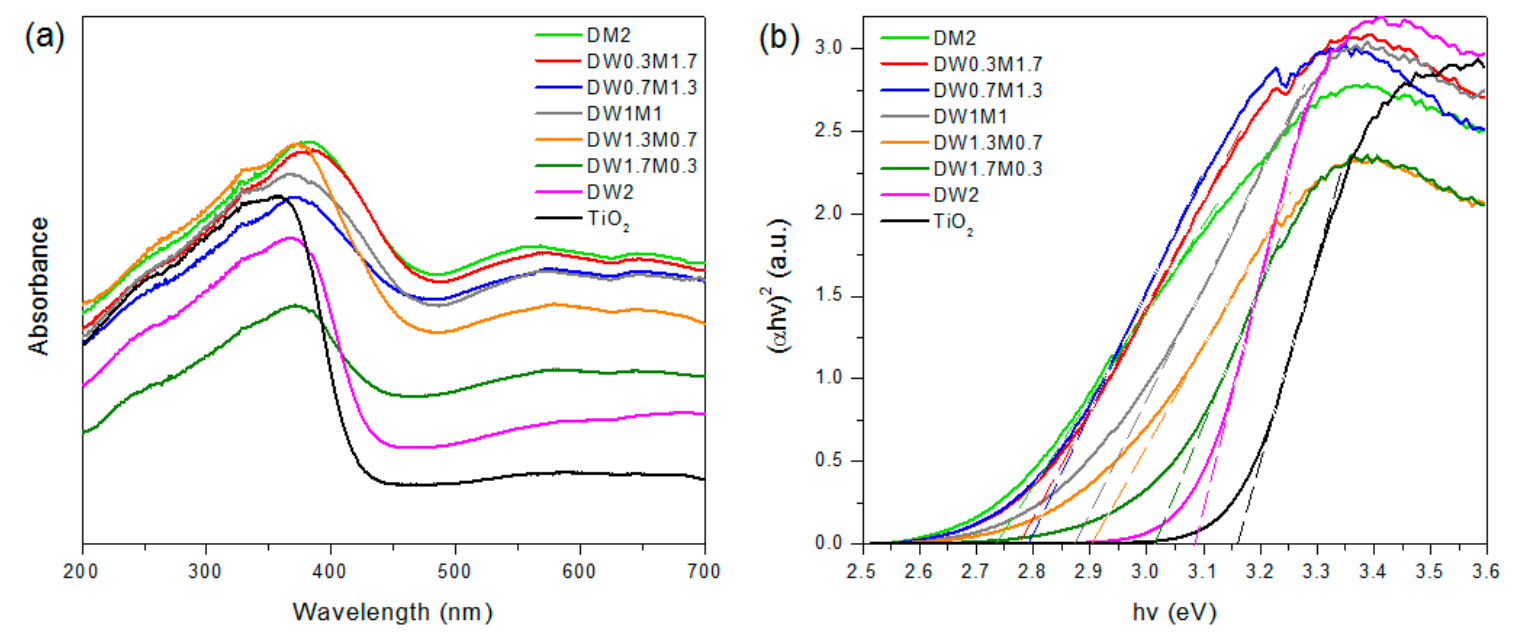

Figure 7. (a) UV-vis absorbance spectra and (b) band gap energies (Tauc plots) of synthesized catalysts.

Table 3. Band gap energy and wavelength of synthesized materials.

\begin{tabular}{ccc}
\hline Sample & Band Gap (eV) & Wavelength (nm) \\
\hline $\mathrm{TiO}_{2}$ & 3.16 & 392 \\
$\mathrm{DM} 2$ & 2.74 & 452 \\
$\mathrm{DW} 0.3 \mathrm{M} 1.7$ & 2.78 & 446 \\
$\mathrm{DW} 0.7 \mathrm{M} 1.3$ & 2.80 & 443 \\
$\mathrm{DW} 1 \mathrm{M} 1$ & 2.87 & 432 \\
$\mathrm{DW} 1.3 \mathrm{M} 0.7$ & 2.90 & 428 \\
$\mathrm{DW} 1.7 \mathrm{M} 0.3$ & 3.01 & 412 \\
$\mathrm{DW} 2$ & 3.08 & 403 \\
\hline
\end{tabular}

X-ray photoelectron spectroscopy (XPS) was used to determine the chemical state of the elements on the surface of the synthesized materials. Figure 8 shows the XPS spectra of Ti $2 \mathrm{p}$ in samples $\mathrm{TiO}_{2}$, DM2, DW2, and DW1M1. Two peaks located with binding energies at $458.1 \mathrm{eV}$ and $463.8 \mathrm{eV}$ are assigned to Ti $2 \mathrm{p}_{3 / 2}$ and Ti $2 \mathrm{p}_{1 / 2}$ states, respectively, and these correspond to $\mathrm{Ti}^{4+}$ into $\mathrm{TiO}_{2}$ lattice. A slight shift towards higher binding energies at $0.3 \mathrm{eV}$ after doping and co-doping with $\mathrm{W}$ and $\mathrm{Mo}$ cations is evidence that these dopant metals are part of the anatase crystalline structure [35]. The $\mathrm{O}$ 1s XPS spectra for the sample co-doped with $1 \mathrm{wt} . \% \mathrm{~W}$ and $1 \mathrm{wt} . \%$ Mo is shown in Figure 9a. The peak at $529.8 \mathrm{eV}$ is attributed to the $\mathrm{Ti}-\mathrm{O}$ bond in $\mathrm{TiO}_{2}$, whereas that at $532.2 \mathrm{eV}$ is assigned to surface hydroxyl groups. In photocatalysis, these hydroxyl groups play an important role, since they react with the holes generated during photoexcitation to produce hydroxyl radicals, which degrade organic 
compounds [36]. Figure $9 \mathrm{~b}$ presents the XPS spectrum in the Mo $3 \mathrm{~d}$ region for sample DW1M1. In this figure, two main peaks, attributed to Mo $3 \mathrm{~d}_{3 / 2}$ and Mo $3 \mathrm{~d}_{5 / 2}$, show contributions of $\mathrm{Mo}^{6+}$ at $233.2 \mathrm{eV}$ and $234.7 \mathrm{eV}$, and $\mathrm{Mo}^{5+}$ at $232.8 \mathrm{eV}$ and $234.3 \mathrm{eV}$. The percentage of these two species in the catalyst surface is $77.5 \%$ and $22.5 \%$ for $\mathrm{Mo}^{6+}$ and $\mathrm{Mo}^{5+}$, respectively. The XPS spectrum shown in Figure 9c corresponds to the $\mathrm{W} 4 \mathrm{f}$ region. As it is observed, the surface of sample DW1M1 is composed of $91.7 \%$ $\mathrm{W}^{6+}$ and $8.3 \% \mathrm{~W}^{5+}$ at $36.0 \mathrm{eV}$ and $34.3 \mathrm{eV}$, respectively. These signals confirm the presence of both $\mathrm{W}$ and Mo dopants on the surface layers of $\mathrm{TiO}_{2}$, which are involved in the photocatalytic reactions.

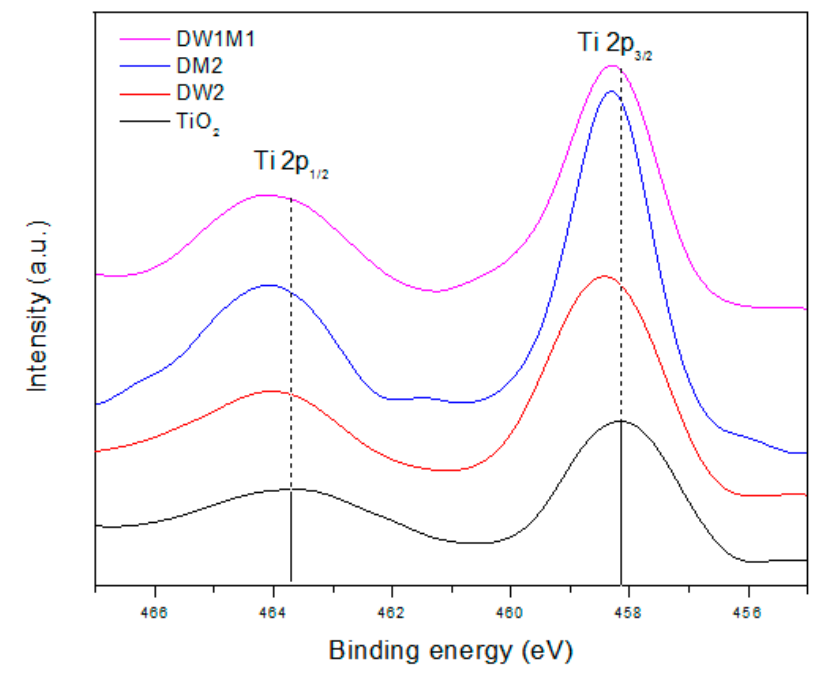

Figure 8. XPS spectra of Ti 2p for undoped, doped, and co-doped $\mathrm{TiO}_{2}$ samples with $\mathrm{W}$ and Mo.
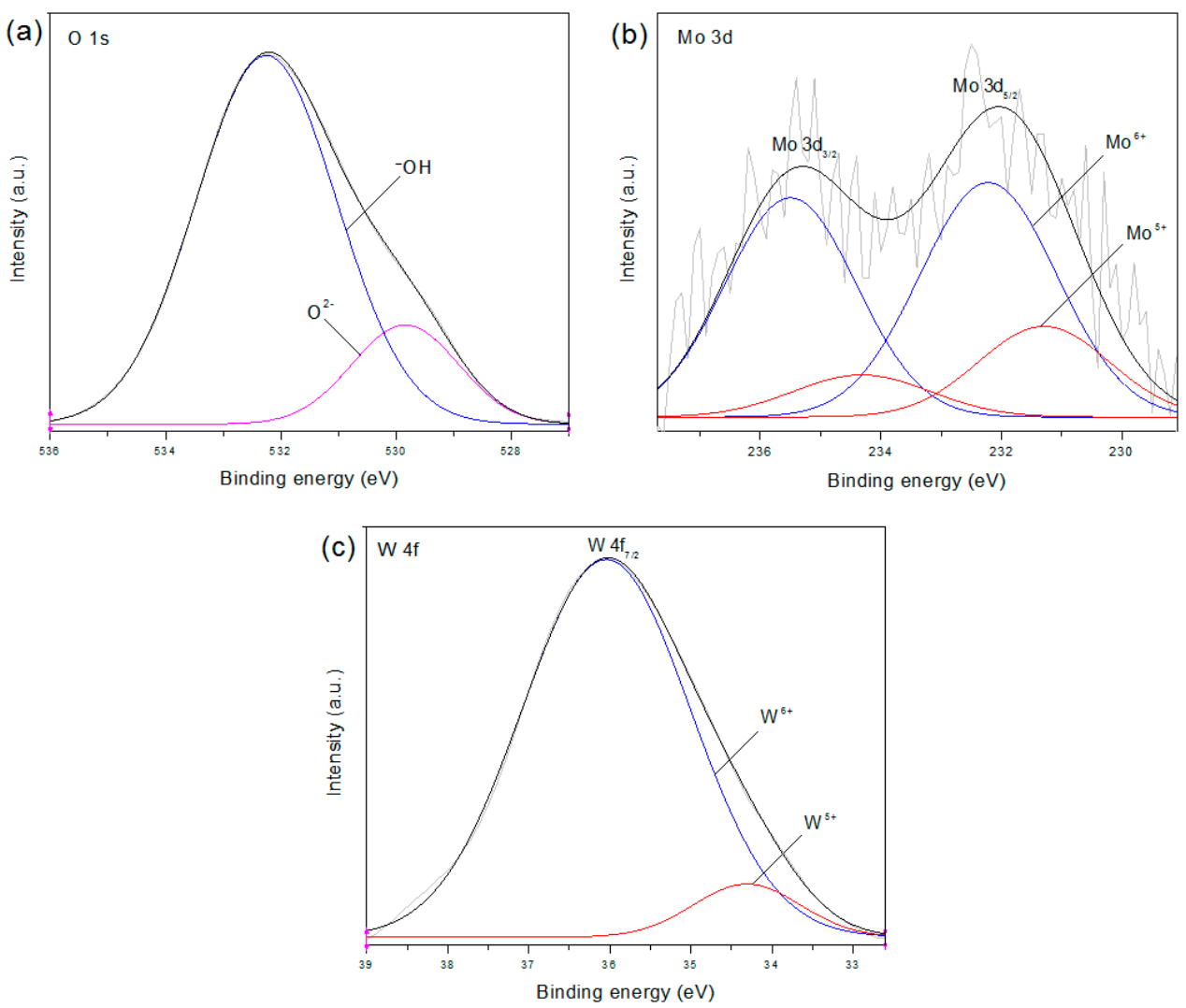

Figure 9. XPS spectra of (a) $\mathrm{O} 1 \mathrm{~s}$, (b) $\mathrm{Mo} 3 \mathrm{~d}$, and (c) $\mathrm{W}$ 4f for co-doped $\mathrm{TiO}_{2}$ sample with $\mathrm{W}$ and Mo cations. 
Figure 10 shows the transmission electron micrographs, the high resolution transmission micrographs, as well as the electron diffraction patterns of mono-doped samples DM2 and DW2, and co-doped sample DW1M1. The TEM images in Figure 10a,d,g for mono-doped and co-doped titania with Mo and $\mathrm{W}$ cations show individual nanoparticles from five to $12 \mathrm{~nm}$ in size. The HRTEM micrographs for samples DM2 and DW2 in Figure 10b,e, exhibit interlayer spacing $(0.35 \mathrm{~nm})$ that corresponds to the (101) plane of anatase crystalline structure. In the HRTEM image for sample co-doped with $1 \mathrm{wt} . \%$ of both cations (Figure 10h); the (101) and (004) planes of anatase phase can be observed [37]. Furthermore, the SAED patterns shown in Figure 10c,f,i indicate a sequence of rings, which are characteristic of the crystalline planes (101), (004), (200), and (105). All these results are consistent with those obtained by the XRD analysis.
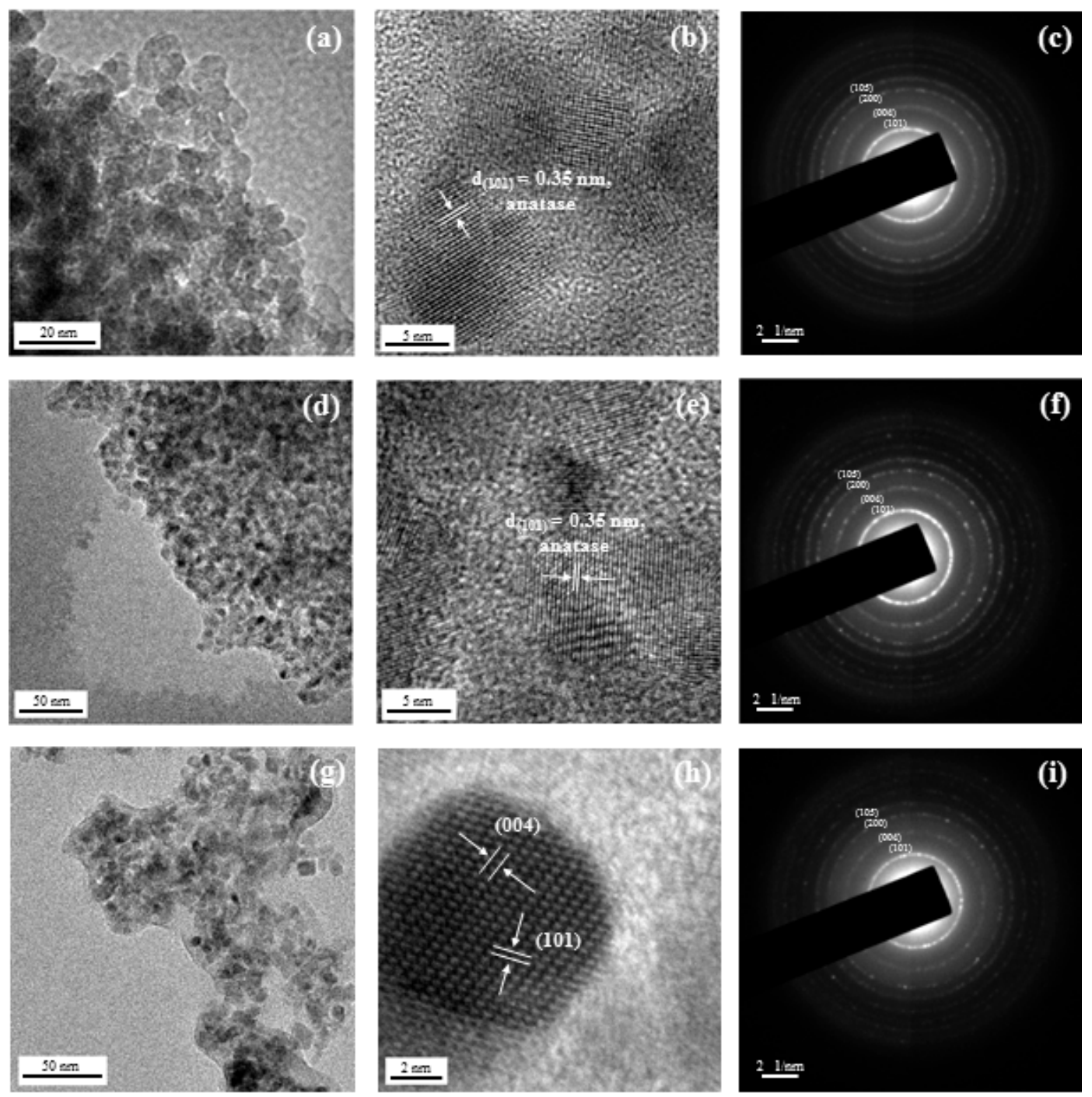

Figure 10. TEM images, HRTEM images and SAED patterns of samples (a-c) DM2, (d-f) DW2, and (g-i) DW1M1.

In order to visualize the dopant atoms in the anatase crystalline structure, Figure 11 shows STEM-HAADF micrographs with corrected aberration of synthesized catalysts DW1, DM1, and DW1M1. It can be observed in Figure 11a (W-mono-doped $\mathrm{TiO}_{2}$ ) that the tungsten atoms are well distributed and they are part of well-defined atomic columns within the anatase phase. However, when titania is mono-doped with molybdenum atoms (Figure 11b), these can have two locations: (i) As being part of the crystalline structure with a good distribution (yellow circles), and (ii) forming some dispersed agglomerates that are not part of the atomic structure (orange circles). On the other hand, 
when $\mathrm{TiO}_{2}$ is co-doped with $\mathrm{W}$ and $\mathrm{Mo}$, the dispersion of both atoms inside the crystalline lattice is favored (atomic agglomerations disappear) (see Figure 11c).
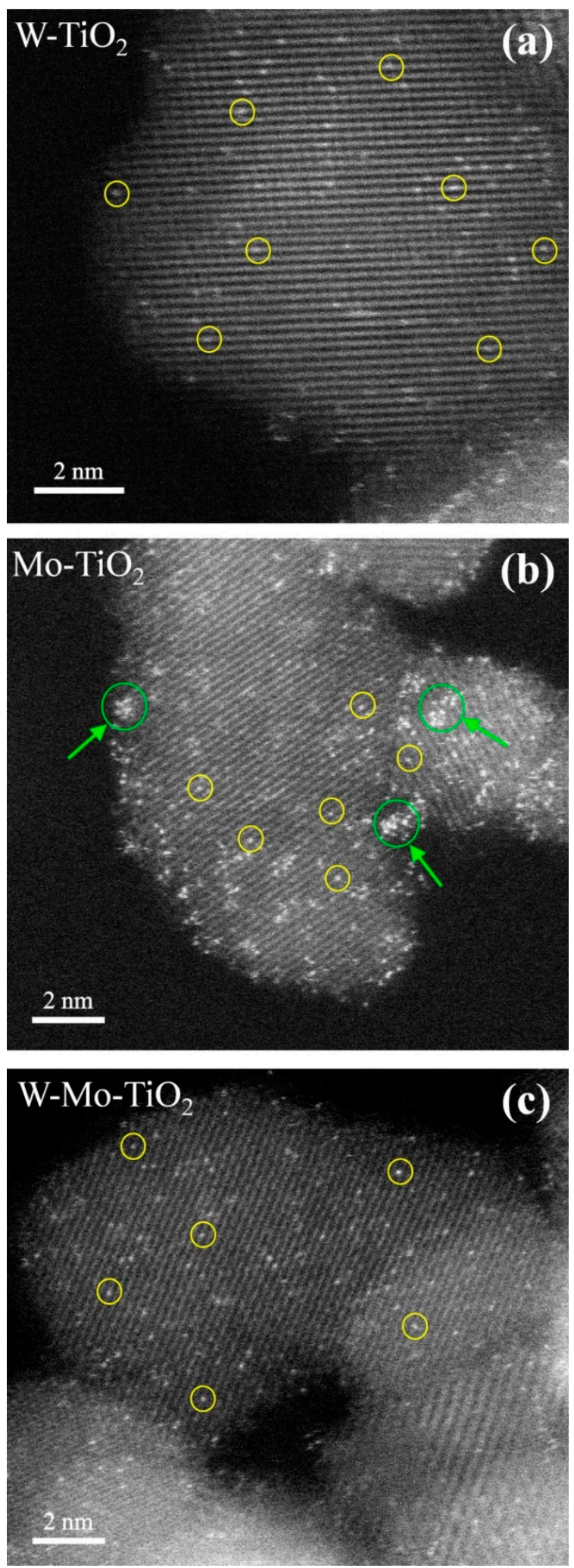

Figure 11. Aberration-corrected STEM-HAADF images of $\mathrm{TiO}_{2}$ mono-doped with (a) $\mathrm{W}$ or (b) $\mathrm{Mo}$, and (c) co-doped with both cations. 


\subsection{Photocatalytic Tests}

All synthesized samples of pure titania, mono-doped, and co-doped with molybdenum and tungsten cations, as well as the commercial catalyst Degussa P25 were evaluated in the photocatalytic degradation of 4-chlorophenol (4CP). Figure 12 shows the photodegradation profiles with $100 \mathrm{~min}$ of reaction as total time. It can be seen that pure synthesized $\mathrm{TiO}_{2}$ and Degussa P25 exhibit the lowest percentages of $4 \mathrm{CP}$ degradation. With respect to the co-doped $\mathrm{TiO}_{2}$ samples, these show better degradation than the mono-doped materials (DM2 and DW2), which might be because of synergistic effects by the two doping species, thus improving their photoactivity. In addition, the co-doped samples exhibited higher surface areas and smaller crystallite sizes than the mono-doped catalysts, which increase the sites density for substrates adsorption during photocatalytic activity [38]. The degradation is gradually improved when the amount of tungsten increases from $0.3 \mathrm{wt} . \%$ to $1 \mathrm{wt} . \%$, achieving more than $97 \%$ for the DW1M1 sample. Concentrations above $1 \mathrm{wt} . \% \mathrm{~W}$ in co-doped $\mathrm{TiO}_{2}$ do not favor photocatalytic activity, which results in less degradation. While the samples co-doped with high molybdenum concentration (DW0.3M1.7 and DW0.7M1.3) exhibited higher radiation absorption, the significant improvement in photoactivity is very likely due to suitable concentration of both dopants. The co-doped $\mathrm{TiO}_{2}$ with $\mathrm{W}: \mathrm{Mo}=1: 1$ ratio exhibits a synergistic effect between the species towards the best photocatalytic activity, since it presents a good radiation absorption capacity (see Figure 7) that favors the generation of $\mathrm{e}^{-} / \mathrm{h}^{+}$pairs, as well as the ability to reduce the recombination processes of the photogenerated charges [39]. The process to inhibit the recombination (Equation (2)) after the $\mathrm{e}^{-} / \mathrm{h}^{+}$pair generation (Equation (1)) is shown in Equations. (3) and (4). The electrons can be trapped by the most stable states of $\mathrm{W}$ and Mo, the $\mathrm{W}^{6+}$ and $\mathrm{Mo}^{6+}$ species, respectively, reaching a local charge compensation that leads to a longer lifetime of the generated holes [40]. In this way, the holes can be trapped by the adsorbed $\mathrm{H}_{2} \mathrm{O}$ or by the $-\mathrm{OH}$ groups on the $\mathrm{TiO}_{2}$ surface (Equations (5) and (6)) (see Figure 9a), allowing the generation of more $\bullet \mathrm{OH}$ radicals, which are responsible for the oxidation of organic compounds (Equation (7)). On the other hand, the redox potentials of the doping species involved should not be left aside. In this case, the potentials of the $\mathrm{Mo}^{6+} / \mathrm{Mo}^{5+}$ and $\mathrm{W}^{6+} / \mathrm{W}^{5+}$ pairs are $+0.4 \mathrm{~V}$ and $-0.03 \mathrm{~V}$, respectively [41,42], and they are more positive than the potential of the $\mathrm{TiO}_{2}$ conduction band $(-0.51 \mathrm{~V})$ [43], so their electronic capture is favored when both are present in titania. The prepared catalysts showed no $4 \mathrm{CP}$ removal due to adsorption, and likewise, the photolysis effect was negligible.

$$
\begin{gathered}
\text { W-Mo- } \mathrm{TiO}_{2}+\mathrm{hv} \rightarrow \mathrm{e}^{-}+\mathrm{h}^{+} \\
\mathrm{e}^{-}+\mathrm{h}^{+} \rightarrow \mathrm{TiO}_{2} \\
\mathrm{~W}^{6+}+\mathrm{e}^{-} \rightarrow \mathrm{W}^{5+} \\
\mathrm{Mo}^{6+}+\mathrm{e}^{-} \rightarrow \mathrm{Mo}^{5+} \\
\mathrm{H}_{2} \mathrm{O}+\mathrm{h}^{+} \rightarrow \bullet \mathrm{OH}+\mathrm{H}^{+} \\
-\mathrm{OH}+\mathrm{h}^{+} \rightarrow \bullet \mathrm{OH} \\
\bullet \mathrm{OH}+4 \mathrm{CP} \rightarrow \rightarrow \mathrm{CO}_{2}+\mathrm{H}_{2} \mathrm{O}+\mathrm{Cl}^{-}
\end{gathered}
$$

The photocatalytic degradation profiles of $4 \mathrm{CP}$ were adjusted to a pseudo-first-order kinetics [44]. Apparent kinetic constants as well as half-life for all catalysts are summarized in Table 4 . It can be seen that the maximum degradation is achieved by using the titania co-doped at $1 \mathrm{wt} . \%$ of both cations with a $4 \mathrm{CP}$ half-life of approximately $20 \mathrm{~min}$, where about $75 \%$ of the initial concentration of $4 \mathrm{CP}$ is degraded in $40 \mathrm{~min}$. 


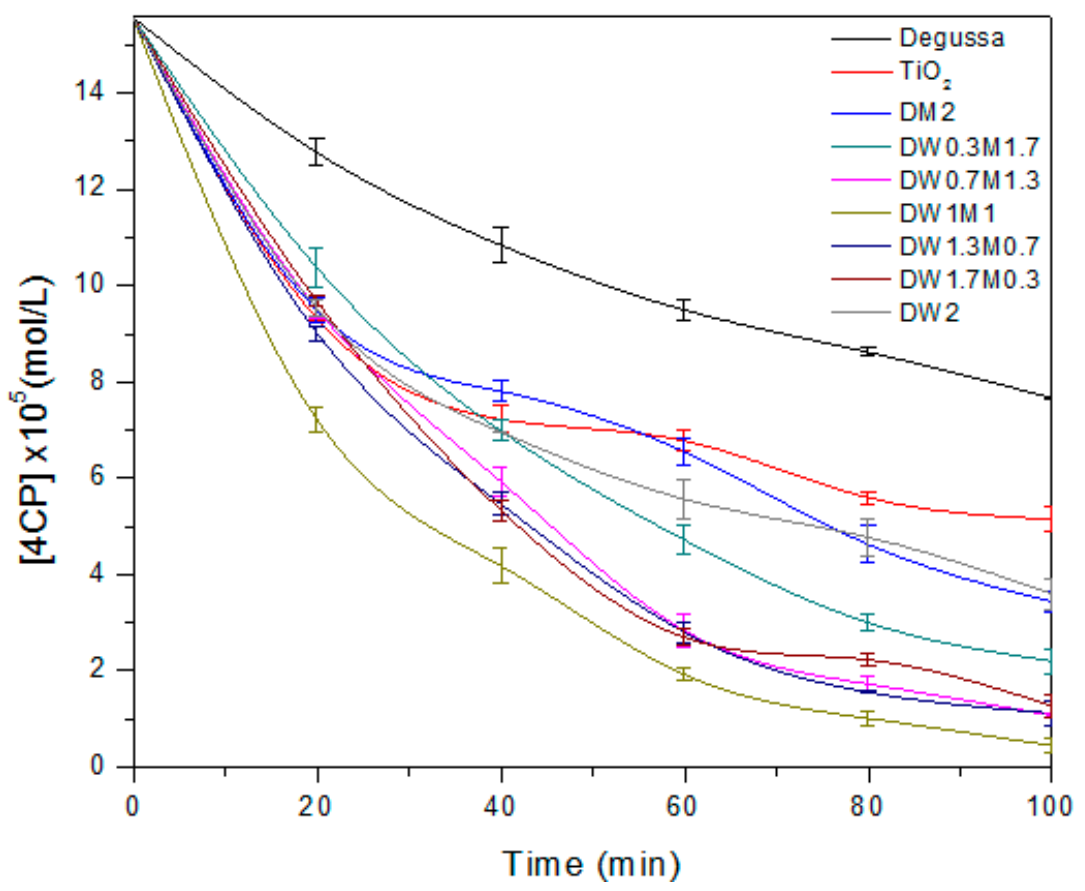

Figure 12. 4-Chlorophenol photodegradation profiles over $\mathrm{TiO}_{2}, \mathrm{Mo}-\mathrm{TiO}_{2}, \mathrm{~W}-\mathrm{TiO}_{2}, \mathrm{~W}-\mathrm{Mo}-\mathrm{TiO}_{2}$, and Degussa P25 catalysts. $[4 \mathrm{CP}]_{0}=15.56 \times 10^{-5} \mathrm{M}, \mathrm{C}_{\text {cat }}=2 \times 10^{-4} \mathrm{~kg} / \mathrm{L}, \mathrm{pH}_{0}=2, \mathrm{~T}=298 \mathrm{~K}$.

Table 4. Removal percentages, apparent kinetic constant, half-time and regression coefficient for 4CP degradation.

\begin{tabular}{lcccc}
\hline \multicolumn{1}{r}{ Catalyst } & 4CP Degradation $\mathbf{( \% )}$ & $\mathbf{k} \times \mathbf{1 0}^{\mathbf{2}} \mathbf{( \mathbf { m i n } ^ { - \mathbf { 1 } } )}$ & $\mathbf{t}_{\mathbf{1 / 2}} \mathbf{( \mathbf { m i n } )}$ & $\mathbf{r}^{\mathbf{2}}$ \\
\hline DM2 & 76 & 1.31 & 52.8 & 0.97 \\
DW0.3M1.7 & 86 & 1.98 & 34.9 & 0.99 \\
DW0.7M1.3 & 93 & 2.75 & 25.2 & 0.99 \\
DW1M1 & 97 & 3.49 & 19.9 & 0.99 \\
DW1.3M0.7 & 93 & 2.73 & 25.4 & 0.99 \\
DW1.7M0.3 & 92 & 2.51 & 27.6 & 0.99 \\
DW2 & 75 & 1.26 & 54.9 & 0.95 \\
$\mathrm{TiO}_{2}$ & 67 & 1.04 & 66.8 & 0.90 \\
Degussa P25 & 51 & 0.67 & 102.9 & 0.97 \\
\hline
\end{tabular}

The percentage of mineralization, which is estimated by the total organic carbon content (TOC), is an important parameter of the degree of deep or complete oxidation of 4-chlorophenol to carbon dioxide and water (Equation (8)) [45].

$$
\mathrm{C}_{6} \mathrm{H}_{5} \mathrm{ClO}+\mathrm{W}-\mathrm{Mo}-\mathrm{TiO}_{2}+\mathrm{hv} \rightarrow \text { Intermediates } \rightarrow \mathrm{CO}_{2}+\mathrm{H}_{2} \mathrm{O}+\mathrm{Cl}^{-}
$$

Figure 13 shows the $4 \mathrm{CP}$ mineralization percentages using the $\mathrm{TiO}_{2}$ catalysts mono and co-doped with $\mathrm{W}$ and/or Mo. W-Mo-co-doped $\mathrm{TiO}_{2}$ with a tungsten weight ratio of $\mathrm{W} /(\mathrm{W}+\mathrm{Mo})=0.5$ showed the highest percentage of mineralization achieving more than $74 \%$. On the other hand, the mono-doped samples (DM2 and DW2) exhibited average mineralization percentages of $50 \%$ and $53 \%$, respectively. 


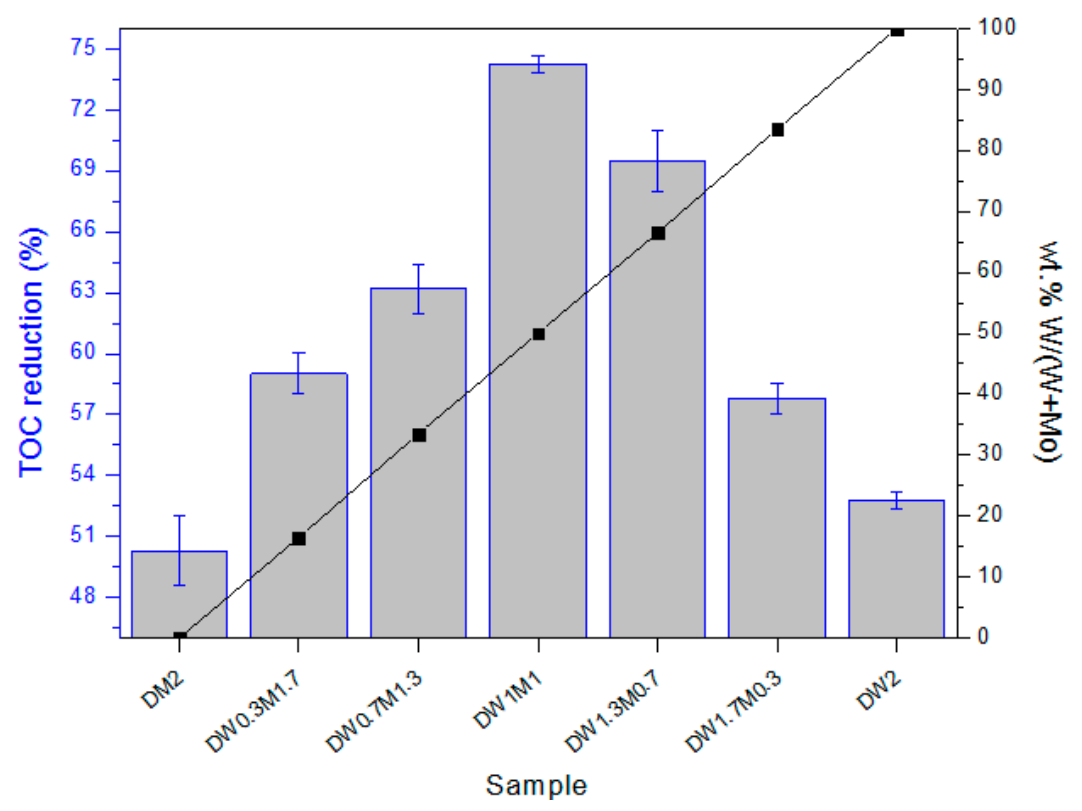

Figure 13. TOC reduction percentages and amount of tungsten dopant on mono-doped and co-doped $\mathrm{TiO}_{2} \cdot[4 \mathrm{CP}]_{0}=15.56 \times 10^{-5} \mathrm{M}, \mathrm{C}_{\text {cat }}=2 \times 10^{-4} \mathrm{~kg} / \mathrm{L}, \mathrm{pH}_{0}=2, \mathrm{~T}=298 \mathrm{~K}$.

Table 5 shows the photocatalytic performance of the synthesized sample DW1M1 in comparison with other reported co-doped $\mathrm{TiO}_{2}$ materials. It can be seen that, although the reaction conditions are a little different, the synthesized material of $\mathrm{W}-\mathrm{Mo}-\mathrm{TiO}_{2}$ exhibits a higher degradation/mineralization percentage of 4-chlorophenol, as well as enhanced kinetic parameters.

Table 5. Photocatalytic performance of $\mathrm{W}$-Mo-co-doped $\mathrm{TiO}_{2}$ compared to other reported co-doped TiO2 materials.

\begin{tabular}{|c|c|c|c|c|c|c|}
\hline Photo-Catalyst & $\begin{array}{c}{[4 \mathrm{CP}]_{0} \times} \\
10^{5}(\mathrm{~mol} / \mathrm{L})\end{array}$ & Radiation & $\begin{array}{c}\text { 4CP Degradation } \\
(\%)\end{array}$ & $\begin{array}{c}\text { 4CP Mineralization } \\
(\%)\end{array}$ & $\begin{array}{l}\mathrm{k} \times 10^{2} \\
\left(\min ^{-1}\right)\end{array}$ & Ref. \\
\hline W-Mo-TiO 2 & 15.56 & UV & 97 (100 min) & $74(100 \mathrm{~min})$ & 3.49 & - \\
\hline $\mathrm{B}-\mathrm{N}-\mathrm{TiO}_{2}$ & 5.00 & UV & 98 (120 min) & - & 3.41 & [46] \\
\hline $\mathrm{N}-\mathrm{F}-\mathrm{TiO}_{2}$ & 7.78 & VL & $72(300 \mathrm{~min})$ & - & - & [47] \\
\hline $\mathrm{C}-\mathrm{W}-\mathrm{TiO}_{2}$ & 50.00 & VL & - & 57 (300 min) & - & [48] \\
\hline
\end{tabular}

The intermediate compounds formed during the photocatalytic degradation of 4-chlorophenol were determined by HPLC. Figure 14 shows the concentration profiles of the main intermediaries when the catalyst DW1M1 is used. The name and structure of these identified intermediaries are summarized in Table 6 . The aromatic ring of 4-chlorophenol can be attacked by hydroxyl radicals in several positions, and for this reason some mechanistic pathways are possible towards the formation of these species (see Figure 15). Furthermore, the generation of hydroxylated compounds is clear evidence of the involvement of hydroxyl radicals in the degradation of 4CP [49]. 


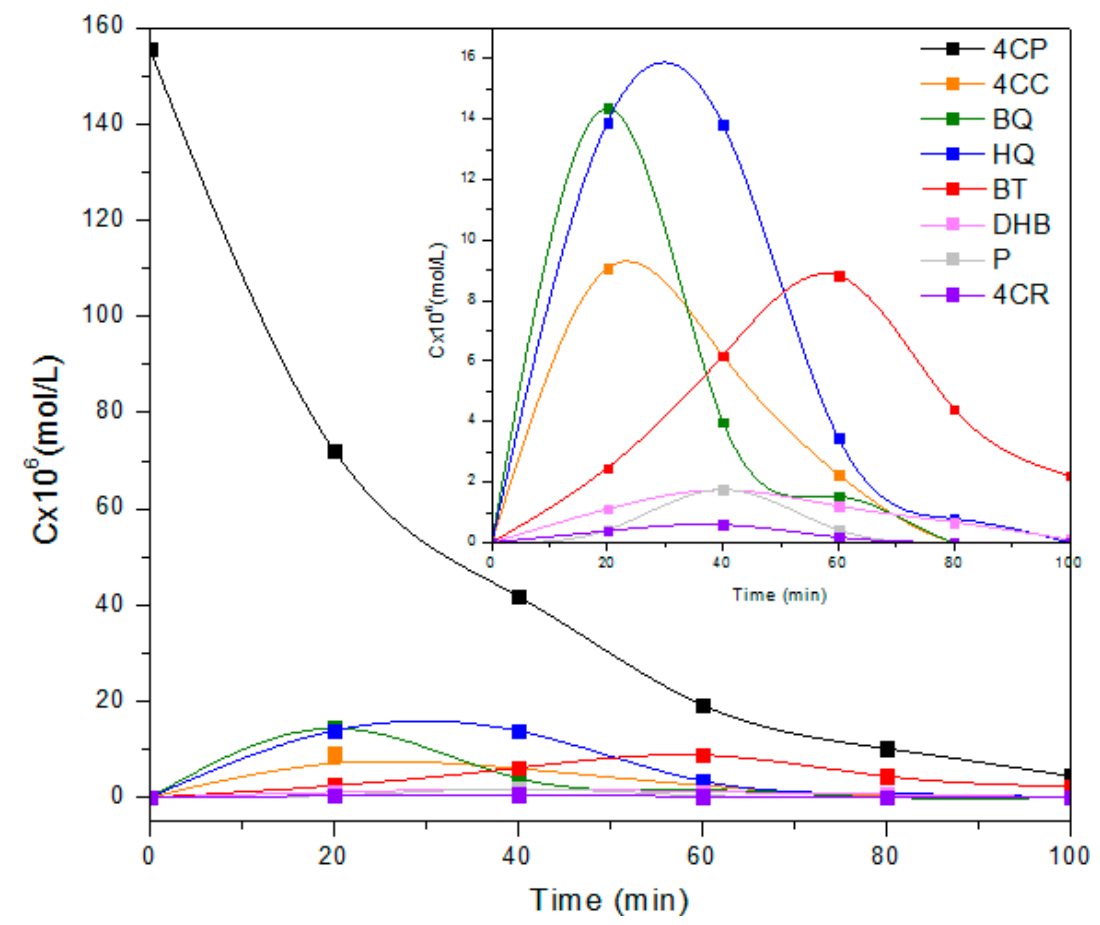

Figure 14. Concentration profiles of intermediates formed during $4 \mathrm{CP}$ photodegradation over $\mathrm{W}-\mathrm{Mo}-\mathrm{TiO}_{2} \cdot[4 \mathrm{CP}]_{0}=15.56 \times 10^{-5} \mathrm{M}, \mathrm{C}_{\text {cat }}=2 \times 10^{-4} \mathrm{~kg} / \mathrm{L}, \mathrm{pH}_{0}=2, \mathrm{~T}=298 \mathrm{~K}$.

Table 6. Intermediate compounds formed in the photocatalytic degradation of 4-chlorophenol over $\mathrm{TiO}_{2}$ co-doped with $\mathrm{W}$ and Mo.

\begin{tabular}{|c|c|c|}
\hline Intermediate Compound ID & Name & Molecular Structure \\
\hline HQ & $\begin{array}{l}\text { Hydroquinone } \\
\text { 1,4-benzenediol } \\
\text { 1,4-dihydroxybenzene }\end{array}$ & \\
\hline $\mathrm{BQ}$ & $\begin{array}{l}\text { Benzoquinone } \\
\text { 1,4-benzoquinone } \\
\text { p-benzoquinone } \\
\text { Quinone }\end{array}$ & \\
\hline $4 \mathrm{CC}$ & $\begin{array}{l}\text { 4-chlorocatechol } \\
\text { 4-chloro-1,2-benzenediol }\end{array}$ & \\
\hline BT & $\begin{array}{l}\text { 1,2,4-benzenetriol } \\
\text { Hydroxyhydroquinone }\end{array}$ & \\
\hline DHB & $\begin{array}{l}\text { 1,2-dihydroxybenzene } \\
\text { 1,2-benzenediol } \\
\text { Catechol } \\
\text { Pyrocatechol }\end{array}$ & \\
\hline $\mathrm{P}$ & $\begin{array}{l}\text { Phenol } \\
\text { Hydroxybenzene }\end{array}$ & \\
\hline $4 C R$ & $\begin{array}{l}\text { 4-chlororesorcinol } \\
\text { 1,3-dihydroxy-4-chlorobenzene }\end{array}$ & \\
\hline
\end{tabular}




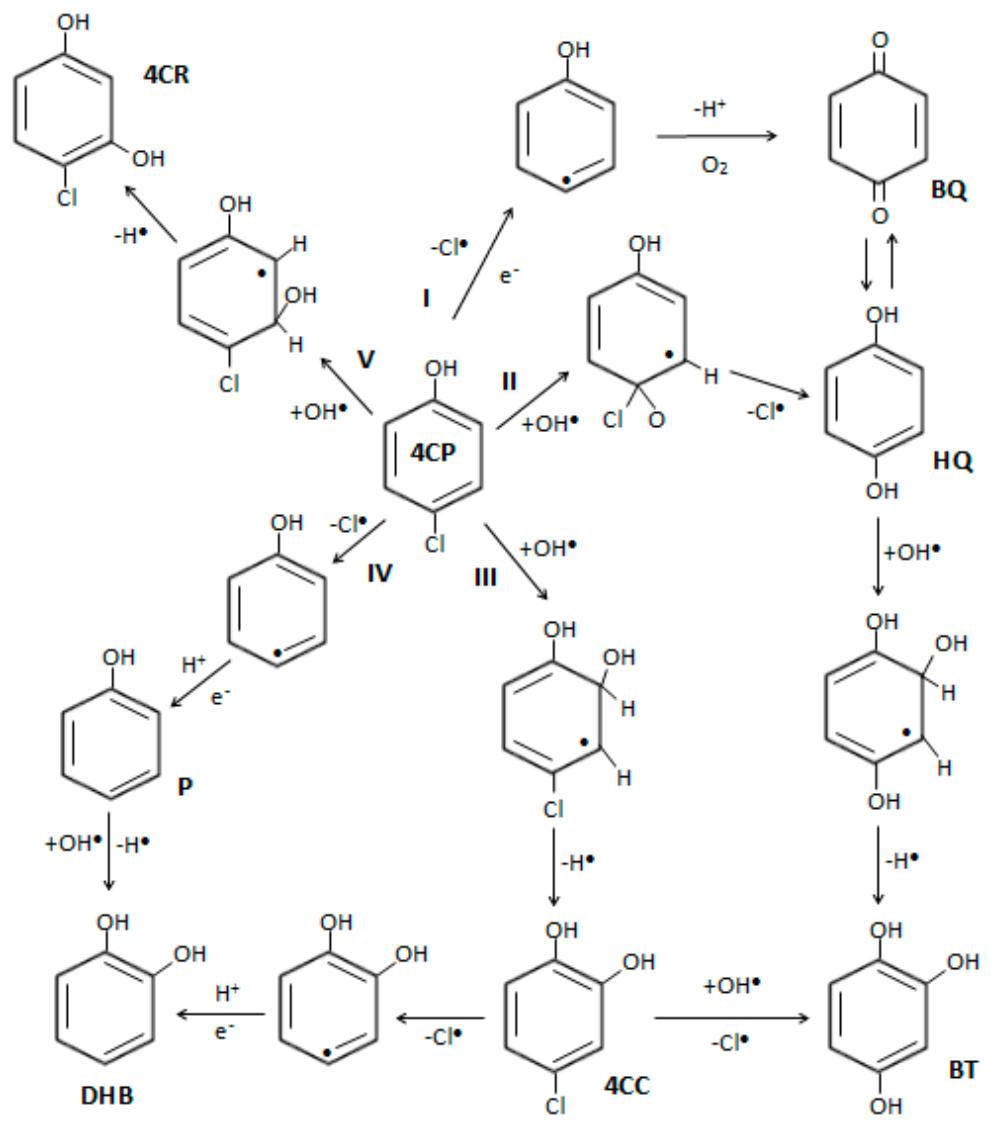

Figure 15. Proposed photocatalytic degradation pathway of 4-chlorophenol by W-Mo- $\mathrm{TiO}_{2}$.

According to Figure 15, the oxidation process of $4 \mathrm{CP}$ is favored towards the quinone route (routes I and II) with maximum concentrations in the first minutes of reaction. Hydroquinone is generated by hydroxylation and dechlorination of $4 \mathrm{CP}$ in para position of the aromatic ring, which can be oxidized to benzoquinone. Additionally, benzoquinone can be formed from the hydroxyphenyl radical via route I [50].

4CP hydroxylation in ortho position generates 4-chlorocatechol (route III). The para-dechlorination of 4CC forms the 1,2-dihydroxyphenyl radical [51], which, when combined with a proton and an electron, produces 1,2-dihydroxybenzene. The peak with the highest concentration of 1,2,4-benzenetriol is found at $60 \mathrm{~min}$, because its formation is after hydroxylation of hydroquinone (route II) or 4-chlorocatechol (route III). The oxidation process of $4 \mathrm{CP}$ can be initiated by the attack of the $\mathrm{C}-\mathrm{Cl}$ bond (route IV) to form the hydroxyphenyl radical [52], which subsequently combined with a proton generates phenol. On the other hand, DHB (1,2-dihydroxybenzene) can also be formed by ortho-hydroxylation of phenol. However, this oxidation route is not favored due to low concentrations of phenol and 1,2-dihydroxybenzene observed during photocatalytic tests (see Figure 14). Similarly, meta-hydroxylation of 4CP generates very little 4-chlororesorcinol concentration (route V). Finally, the aromatic ring of these intermediate compounds is opened by subsequent oxidations to form aliphatic species (organic acids), which are later mineralized to carbon dioxide and water according to Equation (8) [53].

\section{Materials and Methods}

\subsection{Chemicals}

Titanium (IV) butoxide [Ti $\left.\left(\mathrm{OC}_{4} \mathrm{H}_{9}\right)_{4}, 97 \%\right]$, ammonium metatungstate $\left[\left(\mathrm{NH}_{4}\right)_{6} \mathrm{H}_{2} \mathrm{~W}_{12} \mathrm{O}_{40} \cdot x \mathrm{H}_{2} \mathrm{O}\right]$ and ammonium heptamolybdate $\left[\left(\mathrm{NH}_{4}\right)_{6} \mathrm{Mo}_{7} \mathrm{O}_{24} \cdot 4 \mathrm{H}_{2} \mathrm{O}\right]$ served as metal precursors Ti, $\mathrm{W}$, and Mo, respectively. Pluronic $\mathrm{P} 123\left[\mathrm{EO}_{20} \mathrm{PO}_{70} \mathrm{EO}_{20}\right]$ was used as a surfactant. Ethanol $\left(\mathrm{C}_{2} \mathrm{H}_{6} \mathrm{O}, 99.5 \%\right)$ and 
nitric acid $\left(\mathrm{HNO}_{3}, 70 \%\right)$ were employed as solvents and catalysts, respectively. 4-chlorophenol $\left(\mathrm{ClC}_{6} \mathrm{H}_{4} \mathrm{OH}, 99 \%\right)$ and deionized water were used during the photocatalytic tests. All reagents were of analytical grade and supplied by Sigma-Aldrich (St. Louis, MO, USA). Methanol and acetonitrile (HPLC grade) were used to prepare the mobile phases during the chromatographic analysis.

\subsection{Preparation of Undoped, Doped and Co-Doped $\mathrm{TiO}_{2}$}

Pure $\mathrm{TiO}_{2}$ was prepared by mixing ethyl alcohol and $\mathrm{Ti}\left(\mathrm{OC}_{4} \mathrm{H}_{9}\right)_{4}$ under stirring for $15 \mathrm{~min}$. This mixture was added to the P123 surfactant with constant stirring for $30 \mathrm{~min}$ and finally nitric acid was dropwise incorporated to the reaction media. The homogenous mixture was kept under vigorous stirring for $3 \mathrm{~h}$. The molar ratio of reagents Ti(OBu$)_{4}: \mathrm{C}_{2} \mathrm{H}_{6} \mathrm{O}: \mathrm{P} 123: \mathrm{HNO}_{3}$ was maintained constant at 1:18.71:0.018:3.55. To prepare co-doped $\mathrm{TiO}_{2}$, tungsten and/or molybdenum precursors were added before incorporating the $\mathrm{HNO}_{3}$. The resulting solution was dried in a rotary evaporator until a solid was formed. This was subsequently calcined at $300^{\circ} \mathrm{C}$ for $1 \mathrm{~h}$ (surfactant removal) and then at $400{ }^{\circ} \mathrm{C}$ for $4 \mathrm{~h}$ with a heating rate of $1^{\circ} \mathrm{C} / \mathrm{min}$. Various samples with different weight percentages of dopant were synthetized. However, the total amount of dopant (s) was kept constant at $2 \mathrm{wt} . \%$ with respect to titania. The catalysts were labeled as DWAMB. W stands for tungsten and $\mathrm{M}$ for molybdenum. In addition, $\mathrm{A}$ and $\mathrm{B}$ are the weight percentages in samples. The DM2 and DW2 catalysts contain $2 \mathrm{wt} . \%$ molybdenum and $2 \mathrm{wt} . \%$ tungsten, respectively. Commercial $\mathrm{TiO}_{2}$ (Degussa P25) was used for comparison.

\subsection{Characterization of Photocatalysts}

The temperature for the removal of the surfactant during heat treatment was determined by thermogravimetry (TGA 4000, Pyris, Perkin Elmer, Waltham, MA, USA) with $\mathrm{N}_{2}$ gas flow at $20 \mathrm{~mL} / \mathrm{min}$ in a range of 30 to $700{ }^{\circ} \mathrm{C}\left(5{ }^{\circ} \mathrm{C} / \mathrm{min}\right)$. Before and after heat treatment, Infrared spectroscopy (FT-IR, Perkin Elmer Spectrum Two, Waltham, MA, USA) was used. The FT-IR spectra were acquired in the range of 4000-1000 $\mathrm{cm}^{-1}$ and using a resolution of $1 \mathrm{~cm}^{-1}$.

All synthesized samples were analyzed with an X-ray diffractometer (Bruker Advance D8, Billerica, MA, USA) to determine the crystalline properties. Cu K $\alpha$ radiation at $1.5406 \AA$ was used as the $\mathrm{X}$-ray source. The voltage and current applied were $30 \mathrm{kV}$ and $25 \mathrm{~mA}$, respectively. The diffraction patterns were determined over $2 \theta$ range of $20^{\circ}-70^{\circ}$ with a resolution of $0.02^{\circ} 2 \theta / 16 \mathrm{~s}$. The average crystallite size (D) was estimated by the Scherrer equation $D=0.9 \lambda / \beta \cos \theta$, the lattice distortion (d) by $\mathrm{d}=\beta / 4 \operatorname{tg} \theta$, and the lattice parameters according to the Bragg equation $2 \mathrm{dhkl} \sin \theta=\lambda$, where $\lambda$ is the applied wavelength, $\theta$ is the Bragg angle, and $\beta$ is the FWHM value. Raman spectroscopy was also used to determine the structural properties. For this purpose, a Renishaw micro-Raman spectrometer, provided with a laser of $514 \mathrm{~nm}$, was used.

Average pore diameters and specific surface areas of the synthesized materials were obtained through nitrogen adsorption-desorption isotherms on a Quantachrome (Boynton Beach, FL, USA) Autosorb- 1 at $77 \mathrm{~K}$ by BJH and BET methods, respectively. Before measurements, the materials were degassed out for $2 \mathrm{~h}$ at $200{ }^{\circ} \mathrm{C}$.

The band gaps of all samples were determined through UV-vis Diffuse Reflectance Spectroscopy (DRS) using a Perkin Elmer spectrophotometer (Lambda 35, Waltham, MA, USA) equipped with an integration sphere (Labsphere rsape-20). The Kubelka-Munk function $\alpha=(1-R)^{2} / 2 R$ was used to transform the reflectance spectra into absorption spectra, which were then used to estimate the band gap energies by constructing Tauc plots of hv vs. $(\alpha \mathrm{hv})^{2}$ and extrapolating the linear part to $(\alpha \mathrm{hv})^{2}$ equal to zero.

The chemical states of the surface elements present in the materials were examined by X-ray photoelectron spectroscopy (JEOL JPS-9200 spectrometer, Akishima, TYO, Japan) with an Al K $\alpha$ X-ray source. The energy of $\mathrm{C} 1 \mathrm{~s}$ at $284.6 \mathrm{eV}$ was used as a reference for charge correction during the estimation of the binding energies. 
High resolution-transmission electron microscopy (HR-TEM, JEOL-2100 at $200 \mathrm{kV}$, Akishima, TYO, Japan) and selected area electron diffraction (SAED) were used to determine the particle size and crystalline structure. High-angle annular dark-field scanning microscopy with a spherical aberration corrector (ac-HAADF-STEM, JEOL 2200FS+CS, Akishima, TYO, Japan) was used to visualize the doping atoms in the crystalline structures.

\subsection{Photocatalytic activity and analysis}

The photoactivity of all catalysts was evaluated in the degradation of 4-chlorophenol. The constant reaction conditions used were $2 \times 10^{-4} \mathrm{~kg} / \mathrm{L}$ of catalyst loading, $20 \times 10^{-6} \mathrm{~kg} / \mathrm{L}$ of $4 \mathrm{CP}$ and temperature of $298 \mathrm{~K}$. A UV lamp was used as a radiation source with a wavelength and intensity of $254 \mathrm{~nm}$ and $4500 \mu \mathrm{W} / \mathrm{cm}^{2}$, respectively. The 4-chlorophenol solution was adjusted to an initial $\mathrm{pH}$ of 2 and stirred at $1000 \mathrm{rpm}$ to keep the catalyst in suspension. Aliquots were withdrawn from the reactor every $20 \mathrm{~min}$ and subsequently centrifuged to remove the catalyst. The solutions were then analyzed on a UV-vis spectrophotometer (Perkin Elmer Lambda 25, Waltham, MA, USA) to determine the amount of 4-chlorophenol at $280 \mathrm{~nm}$, according to its absorbance peak. The total organic carbon concentration in the solution was measured by using a Shimadzu TOC-L analyzer to evaluate the $4 \mathrm{CP}$ mineralization. The identification of intermediate compounds during $4 \mathrm{CP}$ degradation was carried out by HPLC (Varian 230, isocratic mode, Santa Clara, CA, USA). Ascentis Express C18 column $(2.7 \mu \mathrm{m}$, $3 \mathrm{~cm} \times 4.6 \mathrm{~mm}$, Sigma-Aldrich) with a mobile phase methanol/water $\left(20 / 80 \mathrm{v} / \mathrm{v}, 1.0 \mathrm{~mL} \mathrm{~min}^{-1}\right)$ and Eclipse XDB-C18 column ( $5 \mu \mathrm{m}, 15 \mathrm{~cm} \times 4.6 \mathrm{~mm}$, Agilent, Santa Clara, CA, USA) with a mobile phase acetonitrile/water $(10 / 90 \mathrm{v} / \mathrm{v}, 0.6 \mathrm{~mL} / \mathrm{min})$ were used at $25^{\circ} \mathrm{C}$.

\section{Conclusions}

$\mathrm{TiO}_{2}$ nanoparticles were prepared by mono and co-doping with molybdenum and tungsten cations by the Evaporation-Induced Self-Assembly (EISA) method. All synthesized materials presented anatase crystalline phase and larger specific surface areas than the commercial photocatalyst Degussa P25. The presence of a second cation by co-doping increased the surface area and decreased the crystallinity, as well as changes in lattice parameters due to structural distortion, since the doping species were successfully incorporated into $\mathrm{TiO}_{2}$ lattice. The dopant cations exhibited oxidation states with valence $5+$ and $6+$ in the titania. Low tungsten concentrations by co-doping favored the reduction of the anatase band gap. Raman analysis showed that no additional phases by co-doping were created, and both dopants are distributed inside the anatase. All synthesized materials exhibited photocatalytic activity in the oxidation of 4-chlorophenol and all of them outperformed commercial $\mathrm{TiO} 2 \mathrm{P} 25$. Synergistic effect with an appropriate concentration of both dopant cations improved photocatalytic activity by reducing the recombination of photogenerated charges and by increasing the absorption of radiation to promote their generation. The experiments performed at ambient temperature and during $100 \mathrm{~min}$ showed that titania, co-doped with $1 \mathrm{wt} . \% \mathrm{~W}$ and $1 \mathrm{wt} . \%$, Mo exhibited the best photoactivity among the catalysts studied, with $97 \%$ and $74 \%$ of degradation and mineralization of 4-chlorophenol, respectively. The oxidation route of 4-chlorophenol was favored towards quinones as main intermediates via hydroxyl radicals. Remaining TOC $(26 \%)$ is attributed to 1,2,4-benzenetriol as secondary intermediate and aliphatic compounds.

Author Contributions: J.E.-V. and R.N.-R. designed the experiments and supervised the project; O.A.-G. performed the experiments and analyzed the data; D.A.S.-C. contributed with characterization of materials; O.A.-G. wrote the manuscript; All authors contributed to a review of the manuscript before submission.

Funding: This research was funded by PROMEP-Mexico (financial support through project 103.5/13/S257) and CONACYT-Mexico (project 269093). Scholarship 378292 by CONACYT.

Acknowledgments: Authors are grateful to CCIQS from UAEM-UNAM and CIMAV-Mexico for the granted support. The technical support of Gustavo López Téllez, Alfredo Rafael Vílchis Néstor, Uvaldo Hernández, Citlalit Martínez and Carlos Elías Ornelas Gutiérrez is also acknowledged.

Conflicts of Interest: The authors declare no conflict of interest. 


\section{References}

1. Finčur, N.L.; Krstić, J.B.; Šibul, F.S.; Šojić, D.V.; Despotović, V.N.; Banić, N.D.; Agbaba, J.R.; Abramović, B.F. Removal of alprazolam from aqueous solutions by heterogeneous photocatalysis: Influencing factors, intermediates, and products. Chem. Eng. J. 2017, 307, 1105-1115. [CrossRef]

2. Verbruggen, S.W. $\mathrm{TiO}_{2}$ photocatalysis for the degradation of pollutants in gas phase: From morphological design to plasmonic enhancement. J. Photochem. Photobiol. C Photochem. Rev. 2015, 24, 64-82. [CrossRef]

3. Linsebigler, A.L.; Lu, G.; Yates, J.T. Photocatalysis on $\mathrm{TiO}_{2}$ surfaces: Principles, mechanisms, and selected results. Chem. Rev. 1995, 95, 735-758. [CrossRef]

4. Fujishima, A.; Zhang, X.; Tryk, D.A. $\mathrm{TiO}_{2}$ photocatalysis and related surface phenomena. Surf. Sci. Rep. 2008, 63, 515-582. [CrossRef]

5. Kong, M.; Li, Y.; Chen, X.; Tian, T.; Fang, P.; Zheng, F.; Zhao, X. Tuning the relative concentration ratio of bulk defects to surface defects in $\mathrm{TiO}_{2}$ nanocrystals leads to high photocatalytic efficiency. J. Am. Chem. Soc. 2011, 133, 16414-16417. [CrossRef]

6. Liqiang, J.; Honggang, F.; Baiqi, W.; Dejun, W.; Baifu, X.; Shudan, L.; Jiazhong, S. Effects of Sn dopant on the photoinduced charge property and photocatalytic activity of $\mathrm{TiO}_{2}$ nanoparticles. Appl. Catal. B Environ. 2006, 62, 282-291. [CrossRef]

7. Yang, G.; Yan, Z.; Xiao, T. Low-temperature solvothermal synthesis of visible-light-responsive S-doped $\mathrm{TiO}_{2}$ nanocrystal. Appl. Surf. Sci. 2012, 258, 4016-4022. [CrossRef]

8. Ding, H.; Sun, H.; Shan, Y. Preparation and characterization of mesoporous SBA-15 supported dye-sensitized $\mathrm{TiO}_{2}$ photocatalyst. J. Photochem. Photobiol. A Chem. 2005, 169, 101-107. [CrossRef]

9. Wu, Y.; Liu, H.; Zhang, J.; Chen, F. Enhanced photocatalytic activity of nitrogen-doped titania by deposited with gold. J. Phys. Chem. C 2009, 113, 14689-14695. [CrossRef]

10. Bayati, M.R.; Golestani-Fard, F.; Moshfegh, A.Z. Photo-degradation of methelyne blue over $\mathrm{V}_{2} \mathrm{O}_{5}-\mathrm{TiO}_{2}$ nano-porous layers synthesized by micro arc oxidation. Catal. Lett. 2010, 134, 162-168. [CrossRef]

11. Yang, G.; Jiang, Z.; Shi, H.; Xiao, T.; Yan, Z. Preparation of highly visible-light active N-doped $\mathrm{TiO}_{2}$ photocatalyst. J. Mater. Chem. 2010, 20, 5301-5309. [CrossRef]

12. Wilke, K.; Breuer, H.D. The influence of transition metal doping on the physical and photocatalytic properties of titania. J. Photochem. Photobiol. A Chem. 1999, 121, 49-53. [CrossRef]

13. Choi, W.; Termin, A.; Hoffmann, M.R. The role of metal ion dopants in quantum-sized $\mathrm{TiO}_{2}$ : Correlation between photoreactivity and charge carrier recombination dynamics. J. Phys. Chem. 1994, 98, 13669-13679. [CrossRef]

14. Estrellan, C.R.; Salim, C.; Hinode, H. Photocatalytic activity of sol-gel derived $\mathrm{TiO}_{2}$ co-doped with iron and niobium. React. Kinet. Catal. Lett. 2009, 98, 187-192. [CrossRef]

15. Shi, Z.; Lai, H.; Yao, S.; Wang, S. Photocatalytic activity of Fe and Ce co-doped mesoporous $\mathrm{TiO}_{2}$ catalyst under UV and visible light. J. Chin. Chem. Soc. 2012, 59, 614-620. [CrossRef]

16. Soler-Illia, G.D.A.; Louis, A.; Sanchez, C. Synthesis and characterization of mesostructured titania-based materials through evaporation-induced self-assembly. Chem. Mater. 2002, 14, 750-759. [CrossRef]

17. Al-Ekabi, H.; Serpone, N. Kinetics studies in heterogeneous photocatalysis. I. Photocatalytic degradation of chlorinated phenols in aerated aqueous solutions over titania supported on a glass matrix. J. Phys. Chem. 1988, 92, 5726-5731. [CrossRef]

18. Chang, W.; Kim, H.; Lee, G.Y.; Ahn, B.J. Catalytic hydrodechlorination reaction of chlorophenols by Pd nanoparticles supported on graphene. Res. Chem. Int. 2016, 42, 71-82. [CrossRef]

19. Ruiz-García, C.; Heras, F.; Calvo, L.; Alonso-Morales, N.; Rodriguez, J.J.; Gilarranz, M.A. Platinum and $\mathrm{N}$-doped carbon nanostructures as catalysts in hydrodechlorination reactions. Appl. Catal. B Environ. 2018, 238, 609-617. [CrossRef]

20. Hernandez, S.R.; Kergaravat, S.V.; Pividori, M.I. Enzymatic electrochemical detection coupled to multivariate calibration for the determination of phenolic compounds in environmental samples. Talanta 2013, 106, 399-407. [CrossRef]

21. Janda, V.; Svecova, M. By-products in drinking water disinfection. Chem. List 2000, 94, 905-908.

22. Li, B.; Zhao, Z.; Gao, F.; Wang, X.; Qiu, J. Mesoporous microspheres composed of carbon-coated $\mathrm{TiO}_{2}$ nanocrystals with exposed $\{001\}$ facets for improved visible light photocatalytic activity. Appl. Catal. B Environ. 2014, 147, 958-964. [CrossRef] 
23. Hussain, S.T.; Siddiqa, A.; Siddiq, M.; Ali, S. Iron-doped titanium dioxide nanotubes: A study of electrical, optical, and magnetic properties. J. Nanopart. Res. 2011, 13, 6517-6525. [CrossRef]

24. Lan, X.; Wang, L.; Zhang, B.; Tian, B.; Zhang, J. Preparation of lanthanum and boron co-doped $\mathrm{TiO}_{2}$ by modified sol-gel method and study their photocatalytic activity. Catal. Today 2014, 224, 163-170. [CrossRef]

25. Hsieh, C.-T.; Fan, W.-S.; Chen, W.-Y.; Lin, J.-Y. Adsorption and visible-light-derived photocatalytic kinetics of organic dye on Co-doped titania nanotubes prepared by hydrothermal synthesis. Sep. Purif. Technol. 2009, 67, 312-318. [CrossRef]

26. Nešić, J.; Manojlović, D.D.; Anđelković, I.; Dojčinović, B.P.; Vulić, P.J.; Krstić, J.; Roglić, G.M. Preparation, characterization and photocatalytic activity of lanthanum and vanadium co-doped mesoporous $\mathrm{TiO}_{2}$ for azo-dye degradation. J. Mol. Catal. A Chem. 2013, 378, 67-75. [CrossRef]

27. Ohsaka, T. Temperature dependence of the Raman spectrum in anatase $\mathrm{TiO}_{2}$. J. Phys. Soc. Jpn. 1980, 48, 1661-1668. [CrossRef]

28. Štengl, V.; Velická, J.; Maříková, M.; Grygar, T.M. New generation photocatalysts: how tungsten influences the nanostructure and photocatalytic activity of $\mathrm{TiO}_{2}$ in the UV and visible regions. ACS Appl. Mater. Int. 2011, 3, 4014-4023. [CrossRef]

29. Wu, Y.; Zhang, J.; Xiao, L.; Chen, F. Properties of carbon and iron modified $\mathrm{TiO}_{2}$ photocatalyst synthesized at low temperature and photodegradation of acid orange 7 under visible light. Appl. Surf. Sci. 2010, 256, 4260-4268. [CrossRef]

30. Shojaie, A.F.; Loghmani, M.H. $\mathrm{La}^{3+}$ and $\mathrm{Zr}^{4+}$ co-doped anatase nano $\mathrm{TiO}_{2}$ by sol-microwave method. Chem. Eng. J. 2010, 157, 263-269. [CrossRef]

31. Liu, D.; Wu, Z.; Tian, F.; Ye, B.-C.; Tong, Y. Synthesis of $\mathrm{N}$ and La co-doped $\mathrm{TiO}_{2} / \mathrm{AC}$ photocatalyst by microwave irradiation for the photocatalytic degradation of naphthalene. J. Alloys Compd. 2016, 676, 489-498. [CrossRef]

32. Wang, Q.; Jiang, H.; Zang, S.; Li, J.; Wang, Q. Gd, C., N and P quaternary doped anatase-TiO 2 nanophotocatalyst for enhanced photocatalytic degradation of 4-chlorophenol under simulated sunlight irradiation. J. Alloys Compd. 2014, 586, 411-419. [CrossRef]

33. Kubelka, P.; Munk, F. Ein beitrag zur optik der farbanstriche. Z. Tech. Phys. 1931, 12, 593-601.

34. Gutiérrez-Alejandre, A.; Ramírez, J.; Busca, G. The electronic structure of oxide-supported tungsten oxide catalysts as studied by UV spectroscopy. Catal. Lett. 1998, 56, 29-33. [CrossRef]

35. Li, J.; Li, B.; Li, J.; Liu, J.; Wang, L.; Zhang, H.; Zhang, Z.; Zhao, B. Visible-light-driven photocatalyst of La-N-codoped $\mathrm{TiO}_{2}$ nano-photocatalyst: Fabrication and its enhanced photocatalytic performance and mechanism. J. Ind. Eng. Chem. 2015, 25, 16-21. [CrossRef]

36. Zhang, J.; Xu, L.J.; Zhu, Z.Q.; Liu, Q.J. Synthesis and properties of ( $\mathrm{Yb}, \mathrm{N})-\mathrm{TiO}_{2}$ photocatalyst for degradation of methylene blue (MB) under visible light irradiation. Mater. Res. Bull. 2015, 70, 358-364. [CrossRef]

37. Khan, H.; Berk, D. Characterization and mechanistic study of $\mathrm{Mo}^{+6}$ and $\mathrm{V}^{+5}$ codoped $\mathrm{TiO}_{2}$ as a photocatalyst. J. Photochem. Photobiol. A Chem. 2014, 294, 96-109. [CrossRef]

38. Wang, Q.; Xu, S.; Shen, F. Preparation and characterization of $\mathrm{TiO}_{2}$ photocatalysts co-doped with iron (III) and lanthanum for the degradation of organic pollutants. Appl. Surf. Sci. 2011, 257, 7671-7677. [CrossRef]

39. Wang, Z.; Chen, C.; Wu, F.; Zou, B.; Zhao, M.; Wang, J.; Feng, C. Photodegradation of rhodamine B under visible light by bimetal codoped $\mathrm{TiO}_{2}$ nanocrystals. J. Hazard. Mater. 2009, 164, 615-620. [CrossRef]

40. Wang, S.; Bai, L.N.; Sun, H.M.; Jiang, Q.; Lian, J.S. Structure and photocatalytic property of Mo-doped $\mathrm{TiO}_{2}$ nanoparticles. Powder Technol. 2013, 244, 9-15. [CrossRef]

41. Luo, S.-Y.; Yan, B.-X.; Shen, J. Enhancement of photoelectric and photocatalytic activities: Mo doped $\mathrm{TiO}_{2}$ thin films deposited by sputtering. Thin Solid Films 2012, 522, 361-365. [CrossRef]

42. Tae Kwon, Y.; Yong Song, K.; In Lee, W.; Jin Choi, G.; Rag Do, Y. Photocatalytic behavior of $\mathrm{WO}_{3}$-loaded $\mathrm{TiO}_{2}$ in an oxidation reaction. J. Catal. 2000, 191, 192-199. [CrossRef]

43. Park, H.; Park, Y.; Kim, W.; Choi, W. Surface modification of $\mathrm{TiO}_{2}$ photocatalyst for environmental applications. J. Photochem. Photobiol. C Photochem. Rev. 2013, 15, 1-20. [CrossRef]

44. Wang, Z.; Liu, X.; Li, W.; Wang, H.; Li, H. Enhancing the photocatalytic degradation of salicylic acid by using molecular imprinted S-doped $\mathrm{TiO}_{2}$ under simulated solar light. Ceram. Int. 2014, 40, 8863-8867. [CrossRef]

45. Sharma, S.; Mukhopadhyay, M.; Murthy, Z.V.P. Rate parameter estimation for 4-chlorophenol degradation by UV and organic oxidants. J. Ind. Eng. Chem. 2012, 18, 249-254. [CrossRef] 
46. Yuan, J.; Wang, E.; Chen, Y.; Yang, W.; Yao, J.; Cao, Y. Doping mode, band structure and photocatalytic mechanism of B-N-codoped $\mathrm{TiO}_{2}$. Appl. Surf. Sci. 2011, 257, 7335-7342. [CrossRef]

47. Li, X.; Zhang, H.; Zheng, X.; Yin, Z.; Wei, L. Visible light responsive N-F-codoped $\mathrm{TiO}_{2}$ photocatalysts for the degradation of 4-chlorophenol. J. Environ. Sci. 2011, 23, 1919-1924. [CrossRef]

48. Neville, E.M.; Mattle, M.J.; Loughrey, D.; Rajesh, B.; Rahman, M.; MacElroy, J.M.D.; Sullivan, J.A.; Thampi, K.R. Carbon-Doped $\mathrm{TiO}_{2}$ and Carbon, Tungsten-Codoped $\mathrm{TiO}_{2}$ through Sol-Gel Processes in the Presence of Melamine Borate: Reflections through Photocatalysis. J. Phys. Chem. C 2012, 116, 16511-16521. [CrossRef]

49. Shamaila, S.; Sajjad, A.K.L.; Chen, F.; Zhang, J. Synthesis and characterization of mesoporous-TiO 2 with enhanced photocatalytic activity for the degradation of chloro-phenol. Mater. Res. Bull. 2010, 45, 1375-1382. [CrossRef]

50. Theurich, J.; Lindner, M.; Bahnemann, D.W. Photocatalytic degradation of 4-chlorophenol in aerated aqueous titanium dioxide suspensions: A kinetic and mechanistic study. Langmuir 1996, 12, 6368-6376. [CrossRef]

51. Gaya, U.I.; Abdullah, A.H.; Zainal, Z.; Hussein, M.Z. Photocatalytic treatment of 4-chlorophenol in aqueous $\mathrm{ZnO}$ suspensions: Intermediates, influence of dosage and inorganic anions. J. Hazard. Mater. 2009, 168, 57-63. [CrossRef] [PubMed]

52. Lipczynska-Kochany, E.; Kochany, J.; Bolton, J.R. Electron paramagnetic resonance spin trapping detection of short-lived radical intermediates in the direct photolysis of 4-chlorophenol in aerated aqueous solution. J. Photochem. Photobiol. A Chem. 1991, 62, 229-240. [CrossRef]

53. Pozan, G.S.; Kambur, A. Removal of 4-chlorophenol from wastewater: Preparation, characterization and photocatalytic activity of alkaline earth oxide doped TiO2. Appl. Catal. B Environ. 2013, 129, 409-415. [CrossRef]

(C) 2018 by the authors. Licensee MDPI, Basel, Switzerland. This article is an open access article distributed under the terms and conditions of the Creative Commons Attribution (CC BY) license (http://creativecommons.org/licenses/by/4.0/). 